\title{
Membrane Protein Production and Purification from Escherichia coli and Sf9 Insect Cells
}

\author{
Liu, Yixin
}

Humana

2021

Liu , Y , Pavic , A , Farley , J T , Lousa , C D M , Goldman , A \& Postis , V L G 2021 , Membrane Protein Production and Purification from Escherichia coli and Sf9 Insect Cells . in V L G Postis \& A Goldman (eds), Biophysics of Membrane Proteins . Methods in Molecular Biology , vol. 2168, Humana , pp. 3-49 . https://doi.org/10.1007/978-1-0716-0724-4_1

http://hdl.handle.net/10138/340196

https://doi.org/10.1007/978-1-0716-0724-4_1

unspecified

acceptedVersion

Downloaded from Helda, University of Helsinki institutional repository.

This is an electronic reprint of the original article.

This reprint may differ from the original in pagination and typographic detail.

Please cite the original version. 


\title{
Membrane protein production and purification from Escherichia coli and $S f^{9}$ insect cells.
}

\author{
Yixin Liu ${ }^{1}$, Ana Pavić ${ }^{2,3}$, Joshua T. Farley ${ }^{3}$, Carine de Marcos Lousa ${ }^{3}$, Adrian Goldman ${ }^{1,2}$ \& \\ Vincent L. G. Postis ${ }^{2,3}$ \\ ${ }^{1}$ Molecular and Integrative Biosciences, Faculty of Biological and Environmental Sciences,
University of Helsinki, Helsinki 00790, Finland.
${ }^{2}$ Astbury Centre for Structural Molecular Biology, School of Biomedical Sciences,
University of Leeds, Leeds LS2 9JT, U.K.
${ }^{3}$ Leeds Beckett University, School of Clinical and Applied Sciences, Leeds LS31HE, UK.
}

Correspondence should be addressed to: v.l.g.postis@leedsbeckett.ac.uk

Running head: Membrane protein purification

Doi: 10.1007/978-1-0716-0724-4_1

\begin{abstract}
A major obstacle for studying membrane proteins by biophysical techniques is the difficulty to produce sufficient amount of materials for functional and structural studies. To overexpress the target membrane protein heterologously, especially a eukaryotic protein, a key step is to find the optimal host expression system and perform subsequent expression optimization. In this chapter, we describe protocols for screening membrane protein production using bacteria and insect cells, solubilization screening, large-scale production as well as commonly used affinity chromatography purification methods. We discuss general optimisation conditions such as promoters, tags and describe current techniques that can be used in any laboratory without specialised expensive equipment. Especially for insect cells, GFP-fusions are particularly useful for localisation and in-gel fluorescence detection of the proteins on SDS-PAGE. We give detailed protocols that can be used to screen the best expression and purification conditions for membrane protein study.
\end{abstract}


Key words: Membrane protein, Protein expression, Protein purification, Bacterial expression, Baculovirus-infected insect cells, Affinity chromatography, Green fluorescence protein, In-gel fluorescence.

Abbreviations: MP: membrane proteins, GFP: green fluorescent protein,

\section{Introduction}

Integral membrane proteins (IMPs) are essential in controlling many biological processes, such as cell mobility, nutrient and ion transportation and cell signalling. Approximately $25 \%$ of the proteomes of living organisms are membrane proteins $(\mathbf{1 , 2})$. But due to their essential role in many cellular processes, they represent $70 \%$ of therapeutic drug targets (3). To investigate the biological functions and structures of membrane proteins, isolation of functional IMPs in vitro is usually a prerequisite. Up until now, only 952 unique membrane protein structures have been deposited (4) (http://blanco.biomol.uci.edu/mpstruc/). Numerous factors account for the difficulty of studying membrane proteins at a molecular level - their low natural abundance, low endogenous or heterologous expression and purification yield, poor solubility and stability. Hence, successful production of sufficient amount of pure and active membrane proteins usually require careful design of constructs for overexpression and selection of appropriate expression hosts, expression conditions (strain, media, temperature, induction/infection time etc.), solubilization and purification strategies (58).

Bacteria, yeast, insect and mammalian cell expression systems have all been successfully used (Table 1) and efficient tools have been developed for the expression and purification of membrane proteins in these systems. However, despite years of research, there still appears to be no rule as to which of these systems would be better suited for a given target protein. Very often, the optimum expression organism needs to be experimentally determined. Among all the systems, E. coli remains the most commonly used host to express prokaryote IMPs while eukaryotic IMPs are often better expressed and purified from eukaryotic systems such as insect cells and mammalian cells. 
Large efforts have been reported in the scientific community to overcome some of the expression problems in these systems, including host engineering, optimising expression conditions, addition of fusion tags to increase expression and directed insertion into cell membrane as well as humanisation of PTMs (9-18).

This chapter focuses on summarising straight-forward methods for membrane protein production in E. coli and baculovirus-infected insect cells which can be applied for a wide range of prokaryote and eukaryotic membrane proteins.

\section{Materials}

\subsection{Reagents and buffers for bacterial cell culture}

1. Escherichia coli host strains: BL21-Gold(DE3) (Stratagene), BL21 Star ${ }^{\mathrm{TM}}$ (DE3) (Invitrogen) and C41 (DE3) and C43(DE3) (Lucigen Corporation). The pRARE2 vector (Novagen) can be coexpressed if required (19).

2. Expression constructs: Chosen vector containing the target open reading frame under an appropriate promoter and terminator (discussed in section 3.1)

3. Media for IPTG induction: LB media: Dissolve $10 \mathrm{~g}$ tryptone, $5 \mathrm{~g}$ yeast extract and $10 \mathrm{~g} \mathrm{NaCl}$ (omit $\mathrm{NaCl}$ if the medium is to be used for autoinduction experiments) in $800 \mathrm{~mL} \mathrm{H}_{2} \mathrm{O}$ and adjust to $\mathrm{pH} 7.4$ by addition of $1 \mathrm{M} \mathrm{NaOH}$. Make up volume to 1 litre then sterilise by autoclaving. Add antibiotic to final concentration prior to use. M9 minimal media: Mix $50 \mathrm{~mL} 20 \mathrm{X}$ M9 salts, $0.2 \mathrm{~mL}$ $1 \mathrm{M} \mathrm{CaCl}_{2}, 2 \mathrm{~mL} 1 \mathrm{M} \mathrm{MgSO}_{4}, 20 \mathrm{~mL} \mathrm{20 \%}$ casamino acids and $4 \mathrm{~mL} \mathrm{50 \%} \mathrm{glycerol.} \mathrm{Complete} \mathrm{to} 1$ $\mathrm{L}$ with sterile $\mathrm{H}_{2} \mathrm{O}$ then sterilise by autoclaving. $\mathrm{SB}$ (super broth) media: Dissolve $32 \mathrm{~g}$ tryptone, $20 \mathrm{~g}$ yeast extract and $5 \mathrm{~g} \mathrm{NaCl}$ (omit $\mathrm{NaCl}$ if the medium is to be used for autoinduction experiments) in $800 \mathrm{~mL}$ water and adjust $\mathrm{pH}$ to 7.4 by addition of $1 \mathrm{M} \mathrm{NaOH}$. Make up volume to 
1 litre with $\mathrm{H}_{2} \mathrm{O}$ then sterilise by autoclaving.

4. $1 \mathrm{M}$ isopropyl- $\beta$-D-thiogalactoside (IPTG): Dissolve $5.95 \mathrm{~g}$ IPTG in a final volume of $25 \mathrm{~mL} \mathrm{H}_{2} \mathrm{O}$.

Sterilise by passage through a $0.22 \mu \mathrm{m}$ filter before aliquoting and storing at $-20^{\circ} \mathrm{C}$.

5. Antibiotic selection: Carbenicillin $100 \mathrm{mg} / \mathrm{mL}$ : Dissolve $500 \mathrm{mg}$ carbenicillin in a final volume of $5 \mathrm{~mL} \mathrm{H}_{2} \mathrm{O}$, sterilise by filtration through a $0.22 \mu \mathrm{m}$ filter and store in the dark at $-20^{\circ} \mathrm{C}$. Use at 100 $\mu \mathrm{g} / \mathrm{mL}$ final concentration. Chloramphenicol $30 \mathrm{mg} / \mathrm{mL}$ : Dissolve $150 \mathrm{mg}$ chloramphenicol in 5 $\mathrm{mL} 100 \%$ ethanol and store at $-20^{\circ}$ C. Use at $30 \mu \mathrm{g} / \mathrm{mL}$ final concentration. Kanamycin $50 \mathrm{mg} / \mathrm{mL}$ : Dissolve $500 \mathrm{mg}$ kanamycin in $10 \mathrm{~mL} \mathrm{H}_{2} \mathrm{O}$. Sterilise by filtration through a $0.22 \mu \mathrm{m}$ filter and store at $-20^{\circ} \mathrm{C}$. Use at $50 \mu \mathrm{g} / \mathrm{mL}$ final concentration.

6. Autoinduction media: Complete media for auto-induction ( $\mathrm{M} 9_{\text {auto }}, \mathrm{LB}_{\text {auto }}$ and $\left.\mathrm{SB}_{\text {auto }}\right)$ (per $\mathrm{L}$ ): Add 1 $\mathrm{mL} 1 \mathrm{M} \mathrm{MgSO}_{4}, 20 \mathrm{~mL} 50 \mathrm{X} 5052$ and $50 \mathrm{~mL}$ 20X NSPC (see below) to M9, LB or SB medium lacking $\mathrm{NaCl}$, (see Note $\mathbf{1}$ ) and complete to $1 \mathrm{~L}$. Add antibiotics if needed before use.

50X 5052: $25 \%(\mathrm{w} / \mathrm{v})$ glycerol, $2.5 \%(\mathrm{w} / \mathrm{v})$ glucose, $10 \%(\mathrm{w} / \mathrm{v}) \alpha$-lactose monohydrate. Weigh $25 \mathrm{~g}$ glycerol into a beaker and then add $73 \mathrm{~mL} \mathrm{H}_{2} \mathrm{O}, 2.5 \mathrm{~g}$ glucose and $10 \mathrm{~g} \alpha$-lactose. Stir until dissolved (see Note 2) then sterilise by filtration through a $0.22 \mu \mathrm{m}$ filter.

20X NSPC: $0.5 \mathrm{M} \mathrm{Na}_{2} \mathrm{HPO}_{4}, 0.5 \mathrm{M} \mathrm{KH}_{2} \mathrm{PO}_{4}, 0.1 \mathrm{M} \mathrm{Na}_{2} \mathrm{SO}_{4}, 1 \mathrm{M} \mathrm{NH} 4 \mathrm{Cl}$. Dissolve $7.1 \mathrm{~g} \mathrm{Na}_{2} \mathrm{HPO}_{4}$, $6.8 \mathrm{~g} \mathrm{KH}_{2} \mathrm{PO}_{4}, 1.42 \mathrm{~g} \mathrm{Na}_{2} \mathrm{SO}_{4}$ and $5.35 \mathrm{~g} \mathrm{NH}_{4} \mathrm{Cl}$ in $75 \mathrm{~mL} \mathrm{H}_{2} \mathrm{O}$. Adjust to $\mathrm{pH} 7.0$ using $\mathrm{NaOH}$ then make volume up to $100 \mathrm{~mL}$. Sterilise by autoclaving;

$1 \mathrm{MMgSO}_{4}$ : Dissolve $24.65 \mathrm{~g} \mathrm{MgSO}_{4} \cdot 7 \mathrm{H}_{2} \mathrm{O}$ in a final volume of $100 \mathrm{~mL} \mathrm{H}_{2} \mathrm{O}$ then sterilise by autoclaving or filtration through a $0.22 \mu \mathrm{m}$ filter.

$1 \mathrm{M} \mathrm{CaCl}_{2}$ : Dissolve $14.7 \mathrm{~g} \mathrm{CaCl}_{2} \cdot 2 \mathrm{H}_{2} \mathrm{O}$ in a final volume of $100 \mathrm{~mL} \mathrm{H} \mathrm{H}_{2} \mathrm{O}$ then sterilise by autoclaving or filtration through a $0.22 \mu \mathrm{m}$ filter.

$50 \%(w / v)$ glycerol: Dissolve 100 g glycerol in $\mathrm{H}_{2} \mathrm{O}$ to give a final volume of $200 \mathrm{~mL}$. Sterilise by autoclaving.

$40 \%(w / v)$ glucose: Dissolve $40 \mathrm{~g}$ glucose in $\mathrm{H}_{2} \mathrm{O}$ to give a final volume of $100 \mathrm{~mL}$. Sterilise by filtration through a $0.22 \mu \mathrm{m}$ filter.

$20 X$ M9 salts: Dissolve $120 \mathrm{~g} \mathrm{Na}_{2} \mathrm{HPO}_{4}, 60 \mathrm{~g} \mathrm{KH}_{2} \mathrm{PO}_{4}, 10 \mathrm{~g} \mathrm{NaCl}$ and $20 \mathrm{~g} \mathrm{NH}$ 
and adjust $\mathrm{pH}$ to 7.4 with $10 \mathrm{M} \mathrm{NaOH}$. Make up volume to 1 litre then sterilise by autoclaving. $20 \%(w / v)$ casamino acids: Dissolve $20 \mathrm{~g}$ casamino acids in $\mathrm{H}_{2} \mathrm{O}$ to give a final volume of $100 \mathrm{~mL}$ then sterilise by autoclaving.

\subsection{Reagents for Total Membrane purification from bacterial culture.}

1. Resuspension buffer: $20 \mathrm{mM}$ Tris $\mathrm{pH} 8$

2. $10 X$ PBS (Phosphate-buffered saline) $\mathrm{pH}$ 7.4: $100 \mathrm{mM} \mathrm{Na}_{2} \mathrm{HPO}_{4}, 18 \mathrm{mM} \mathrm{KH}_{2} \mathrm{PO}_{4}, 1370 \mathrm{mM}$ $\mathrm{NaCl}, 40 \mathrm{mM} \mathrm{KCl}, \mathrm{pH}$ 7.4. Dissolve $80 \mathrm{~g} \mathrm{NaCl}, 3 \mathrm{~g} \mathrm{KCl}, 14.4 \mathrm{~g} \mathrm{Na}_{2} \mathrm{HPO}_{4}$ and $2.4 \mathrm{~g} \mathrm{KH}_{2} \mathrm{PO}_{4}$ in $800 \mathrm{~mL}$ water, adjust $\mathrm{pH}$ to 7.4 and make up the volume to 1 litre. Sterilize by autoclaving for long term storage.

3. $10 X$ TBS (Tris-buffered saline): $500 \mathrm{mM}$ Tris- $\mathrm{HCl}, 1.5 \mathrm{M} \mathrm{NaCl}, \mathrm{pH}$ 7.5. Dissolve $60.57 \mathrm{~g}$ Tris and $87.66 \mathrm{~g} \mathrm{NaCl}$ in $900 \mathrm{~mL} \mathrm{H}_{2} \mathrm{O}$, adjust $\mathrm{pH}$ to 7.5 with $\mathrm{HCl}$ and then make up volume to 1 litre.

4. $I X$ TBS-T $0.1 \%$ (Tris-buffered saline Tween): Dilute $100 \mathrm{~mL}$ of $10 \mathrm{X}$ TBS and add $1 \mathrm{~mL}$ Tween 20. Adjust to 1 litre with $\mathrm{H}_{2} \mathrm{O}$.

\subsection{Reagents and buffers for Western blot or dot blot}

1. Cell lysis solution: $50 \mathrm{mM}$ HEPES, $5 \mathrm{mM} \mathrm{MgCl}, 1 \%$ (v/v) Triton X-100, $25 \%$ sucrose, $10 \mathrm{U}$ $\mathrm{mL}^{-1}$ OmniCleave endonuclease, $0.1 \mathrm{mg} \mathrm{mL}^{-1}$ lysozyme, $\mathrm{pH}$ 8.0. Dissolve $1.192 \mathrm{~g}$ HEPES, 25 g sucrose, $0.048 \mathrm{~g} \mathrm{MgCl}_{2}$ and $1 \mathrm{~mL}$ Triton X-100 in $80 \mathrm{~mL} \mathrm{H} \mathrm{H}_{2} \mathrm{O}$, adjust $\mathrm{pH}$ to 8 with $5 \mathrm{M}$ $\mathrm{NaOH}$, then make up volume to $100 \mathrm{~mL}$. Store in aliquots at $-20^{\circ} \mathrm{C}$. Just before use add $10 \mathrm{U}$ $\mathrm{mL}^{-1}$ OmniCleave endonuclease (Epicentre Biotechnologies) and $0.1 \mathrm{mg} \mathrm{mL}^{-1}$ lysozyme.

2. Denaturing solution for dot blot: $100 \mathrm{mM}$ Tris-HCl, $8 \mathrm{M}$ guanidinium chloride, $\mathrm{pH}$ 8.0: 
Dissolve 76.4 g guanidine hydrochloride in $50 \mathrm{~mL} 200 \mathrm{mM}$ Tris-HCl, $\mathrm{pH}$ 8.0, plus sufficient $\mathrm{H}_{2} \mathrm{O}$ to give a final volume of $100 \mathrm{~mL}$ (see Note 3).

3. Blocking buffer: $3 \%$ bovine serum albumin (BSA) in TBST. Dissolve $3 \mathrm{~g}$ BSA in $100 \mathrm{~mL}$ TBST.

4. Bicinchonic acid (BCA) reagent (Thermo Scientific).

5. cOmplete ${ }^{\mathrm{TM}}$, EDTA-free Protease Inhibitor Cocktail Tablets (Roche Diagnostics Ltd.).

\subsection{Reagents for Detergent screening}

1. Solubilisation buffer: $20 \mathrm{mM}$ Tris $\mathrm{pH} 7.4,500 \mathrm{mM} \mathrm{NaCl}, 15 \mathrm{mM}$ imidazole, $20 \%$ glycerol, $1 \mathrm{X}$ cOmplete $^{\mathrm{TM}}$, EDTA-free Protease Inhibitor Cocktail, pH 7.4.

2. Detergents: prepare $25 \% \mathrm{v} / \mathrm{w}$ in water for DDM (n-dodecyl- $\beta$-D-maltoside), DM (n-Decyl- $\beta$ D-Maltopyranoside), LDAO (Lauryldimethylamine oxide), C12E8 (Dodecyl Octaethylene Glycol Ether) (Anatrace). Weigh 2.5g and solubilise in $10 \mathrm{~mL}$ water. Aliquot in $1 \mathrm{~mL}$ tubes and store at $-20^{\circ}$ C. (see Note 4$)$

\subsection{Reagents and buffers for purification of His-tagged proteins by immobilised metal affinity chromatography (IMAC)}

1. HisPurTM cobalt resin (ThermoScientific).

2. 3 M imidazole, $\mathrm{pH}$ 7.4: Dissolve $20.42 \mathrm{~g}$ imidazole in $\sim 80 \mathrm{~mL} \mathrm{H}_{2} \mathrm{O}$, adjust $\mathrm{pH}$ to 7.4 with $1 \mathrm{M}$ $\mathrm{NaOH}$ then make up to a final volume of $100 \mathrm{~mL}$. For making buffers with low concentrations of imidazole, make a $1 \mathrm{M}$ sub-stock by dilution in water.

3. $3 \mathrm{M} \mathrm{NaCl}$ : Dissolve $87.66 \mathrm{~g} \mathrm{NaCl}$ in $\mathrm{H}_{2} \mathrm{O}$ to give a final volume of $500 \mathrm{~mL}$. 
4. IMAC solubilisation buffer: $20 \mathrm{mM}$ Tris $\mathrm{pH} 7.4,500 \mathrm{mM} \mathrm{NaCl}, 15 \mathrm{mM}$ imidazole, $20 \%$ glycerol,1X cOmplete ${ }^{\mathrm{TM}}$, EDTA-free Protease Inhibitor Cocktail, pH 7.4.

5. IMAC wash buffer 1: $20 \mathrm{mM}$ Tris $\mathrm{pH} 7.4,250 \mathrm{mM} \mathrm{NaCl}, 15 \mathrm{mM}$ imidazole, 10\% glycerol, 0.05\% DDM, $1 \mathrm{X}$ cOmplete ${ }^{\mathrm{TM}}$, EDTA-free Protease Inhibitor Cocktail, $\mathrm{pH}$ 7.4.

6. IMAC wash buffer 2: $20 \mathrm{mM}$ Tris $\mathrm{pH} 7.4,250 \mathrm{mM} \mathrm{NaCl}, 50 \mathrm{mM}$ imidazole, $10 \%$ glycerol, 0.05\% DDM, $1 \mathrm{X}$ cOmplete ${ }^{\mathrm{TM}}$, EDTA-free Protease Inhibitor Cocktail, pH 7.4.

7. IMAC elution buffer: $20 \mathrm{mM}$ Tris $\mathrm{pH} 7.4,250 \mathrm{mM} \mathrm{NaCl}, 250 \mathrm{mM}$ imidazole, $10 \%$ glycerol, 0.05\% DDM, $1 \mathrm{X}$ cOmplete ${ }^{\mathrm{TM}}$, EDTA-free Protease Inhibitor Cocktail, pH 7.4.

\subsection{Insect cell culture and baculovirus-infected insect cells (BIIC) preparation}

1. Spodoptera frugiperda (Sf9) cells (Fisher Scientific)

2. SF900II medium (Gibco), Xpress medium (Lonza)

3. $0.4 \%$ Trypan blue

4. Double distilled $\mathrm{H}_{2} \mathrm{O}\left(\mathrm{ddH}_{2} \mathrm{O}\right.$, sterile $)$

5. Heparin (filter sterilised)

6. Bacmid LB agar plate which contains $50 \mathrm{mg} / \mathrm{L}$ kanamycin, $7 \mathrm{mg} / \mathrm{L}$ gentamicin, $10 \mathrm{mg} / \mathrm{L}$ tetracycline, $100 \mathrm{mg} / \mathrm{L}$ Bluo-gal and $40 \mathrm{mg} / \mathrm{L}$ IPTG.

7. Bacmid cell resuspension buffer: $50 \mathrm{mM}$ Tris-HCl, $\mathrm{pH}$ 8.0, $10 \mathrm{mM}$ EDTA, $200 \mathrm{mg} / \mathrm{L}$ RNase A.

8. Bacmid cell lysis buffer: $0.2 \mathrm{M} \mathrm{NaOH}, 1 \%$ SDS.

9. Bacmid cell neutralization buffer: $3 \mathrm{M} \mathrm{KAc}, \mathrm{pH}$ 5.5.

10. Isopropanol (filter sterilised)

11. Xtreme Gene HD (Roche) 
12. Antibiotics to be added on the day of transfection for large-scale expression (shown as final concentration): $10 \mathrm{mg} / \mathrm{L}$ gentamicin, $0.25 \mathrm{mg} / \mathrm{L}$ Amphotericin B, 100,000 U/L penicillin and $100,000 \mathrm{mg} / \mathrm{L}$ streptomycin.

13. 1.5-mL Eppendorf tubes, $15-\mathrm{mL}$ and 50-mL falcon tubes and opaque falcon tubes (Sigma).

14. 24-well deep-well plates and gas-permeable plate seals (4titude).

15. 6-well plates (Greiner), T-25 and T-75 tissue culture plates (Sigma).

16. Autoclavable $250 \mathrm{ml}, 500 \mathrm{~mL}$ and $1 \mathrm{~L}$ non-baffled glass flasks (VWR).

17. $2 \mathrm{~L}$ shaker reagent bottles (VITLAB) and screw caps with aperture (BOLA) to be used with gas-permeable plate seals (4titude). Autoclave before use.

18. Cryogenic-vials (1.2 mL capacity, Fisher Scientific)

19. BIIC freezing medium containing Xpress medium (or SF900II medium), $5 \%$ fetal bovine serum (FBS, Gibco), and 10\% dimethyl sulfoxide (DMSO) (cell-culture grade).

20. Freezing Container "Mr. Frosty" (Invitrogen) with isopropanol.

21. (Plaque assay) Sterile $4 \%$ agarose

22. (Plaque assay) $1.3 \times$ Sf-900 medium (Thermofisher)

\subsection{Insect cells Membrane preparation and solubilization}

1. 10x detergent stocks made by dissolving detergent powder (Anatrace) in $\mathrm{H}_{2} \mathrm{O}: 10 \%$ FosCholine 12 (FC-12) with 2\% cholesteryl hemisuccinate (CHS), 10\% n-Dodecyl- $\beta$-DMaltoside (DDM) with 2\% CHS, 10\% lauryl maltose neopentyl glycol (LMNG) with 2\% CHS.

2. $40 \mu \mathrm{m}$ nylon cell strainer (Fisher Scientific)

3. Insect cell resuspension buffer: $10 \mathrm{mM}$ HEPES, $\mathrm{pH} 8,1 \mathrm{mM} \mathrm{CaCl}_{2}, 0.1 \mathrm{mg} / \mathrm{mL}$ DNAse I, protease inhibitor tablet (Pierce, 1 tablet in $50 \mathrm{~mL}$ buffer). 
4. Sucrose buffer A: $20 \mathrm{mM}$ HEPES pH $8,0.15 \mathrm{M}$ sucrose, $1 \mathrm{mM} \mathrm{CaCl} 2,1 \mathrm{mM}$ PMSF, 1 $\mu \mathrm{g} / \mathrm{mL}$ leupeptin, protease inhibitor tablet (Pierce, 1 tablet in $50 \mathrm{~mL}$ buffer).

5. Sucrose buffer $B$ : $20 \mathrm{mM}$ HEPES $\mathrm{pH} 8,0.75 \mathrm{M}$ sucrose, $1 \mathrm{mM} \mathrm{CaCl} 2,1 \mathrm{mM}$ PMSF, 3 $\mu \mathrm{g} / \mathrm{mL}$ leupeptin, $1 \mu \mathrm{g} / \mathrm{mL}$ pepstatin A.

6. Binding buffer: $20 \mathrm{mM}$ HEPES, $\mathrm{pH} 8,150 \mathrm{mM} \mathrm{NaCl}, 1 \mathrm{mM} \mathrm{CaCl}, 10 \%$ glycerol.

7. Solubilization buffer: $20 \mathrm{mM}$ HEPES, $\mathrm{pH} 8,150 \mathrm{mM} \mathrm{NaCl}, 1 \mathrm{mM} \mathrm{CaCl}_{2}, 10 \%$ glycerol, $1 \% \mathrm{LMNG}, 0.2 \% \mathrm{CHS}$ or other detergents.

8. 4x sodium dodecyl sulfate (SDS) loading dye (reduced): $200 \mathrm{mM}$ Tris/HCl, $\mathrm{pH} 6.8,8 \%$ SDS, $0.4 \%$ bromophenol blue, $40 \%$ glycerol, $10 \%$ 2-mercaptoethanol.

\subsection{Purification of solubilized membrane proteins from insect cells}

1. Washing buffer A: $20 \mathrm{mM}$ HEPES, pH $8,300 \mathrm{mM} \mathrm{NaCl}, 1 \mathrm{mM} \mathrm{CaCl} 2,10 \%$ glycerol, $0.2 \%$ LMNG, $0.04 \%$ CHS.

2. Washing buffer $B$ : 20mM HEPES, $\mathrm{pH} 8,300 \mathrm{mM} \mathrm{NaCl}, 1 \mathrm{mM} \mathrm{CaCl}_{2}, 10 \%$ glycerol, $0.01 \%$ LMNG, $0.002 \%$ CHS, $10 \mathrm{mM}$ imidazole.

3. Elution buffer: $20 \mathrm{mM}$ HEPES, $\mathrm{pH} 8,300 \mathrm{mM} \mathrm{NaCl}, 1 \mathrm{mM} \mathrm{CaCl} 2,10 \%$ glycerol, $0.01 \%$ LMNG, 0.002\% CHS, $250 \mathrm{mM}$ imidazole

4. Desalting buffer: $20 \mathrm{mM}$ HEPES, pH $8,150 \mathrm{mM} \mathrm{NaCl}, 1 \mathrm{mM} \mathrm{CaCl}_{2}, 10 \%$ glycerol, 0.01\% LMNG, $0.002 \%$ CHS.

5. Regeneration buffer: $0.1 \mathrm{M}$ glycine, $\mathrm{pH}$ 3.0.

6. Ni-NTA resin (Qiagen).

7. Anti-Flag resin (Biomake).

8. Poly-Flag peptide (Biomake). 


\subsection{Lab apparatus}

1. Temperature-controlled shaker incubator (Innova 44).

2. Temperature-controlled static incubator (Memmert IN30).

3. Automated cell counter and cell counting slices (Biorad).

4. Light microscope.

5. Confocal Microscope.

6. Dounce homogenizer.

7. Emulsiflex or Cell Disruptor, e.g. TS series continuous cell disruptor (Constant Systems, UK.

8. Table-top temperature-controlled incubator (Biosan, TS-100C).

9. Refrigerated Centrifuges and tubes.

10. Centrifugal concentrators.

11. Refrigerated Ultracentrifuges (Beckman with TL110, Ti45 and Ti70.1 rotors; Sorval MX120+ with S100-AT3 rotor) and suitable ultracentrifugation tubes.

12. Equipment for sodium dodecyl sulfate polyacrylamide gel electrophoresis (SDS-PAGE).

13. Equipment for electrophoretic transfer of proteins for western blotting (WB).

14. Gravity-flow chromatography columns.

15. Nanodrop (Fisher Scientific).

16. UV spectrophotometer for Bradford assay.

17. Dialysis tubing.

18. Liquid nitrogen cryo-storage.

19. Water bath $\left(37^{\circ} \mathrm{C}, 42^{\circ} \mathrm{C}\right.$ and $\left.70^{\circ} \mathrm{C}\right)$

20. Äkta Fast Protein Liquid Chromatography (FPLC) system (GE Healthcare) or equivalent.

21. Freezing container Mr Frosty 


\section{Membrane protein expression in E. coli}

E. coli offers the advantage of being a very easy, cheap and versatile system readily available in most laboratories. Many prokaryotic and eukaryotic membrane proteins structures have therefore been solved after expression in E.coli (Table 1). The lack of glycosylation in E.coli can sometimes be a setback for expression of eukaryotic membrane proteins which often depend on glycosylations for their function. If available however, the alternative use of prokaryotic homologues can provide valuable structural information that can often be applied to the corresponding eukaryotic proteins. Therefore, E. coli still represents the first expression model system used to test expression of membrane proteins before moving on to more complex and costly systems. Many improvements have been implemented in the last 20 years and systematic testing of optimised conditions is now available to most laboratories. Here we describe the most common ones.

\subsection{Small scale optimization of protein expression}

Every membrane protein is unique. As such, it is crucial that the best expression condition is found. Here we describe various steps that can be undertaken to find the right conditions for a given target protein. Before starting, however, two factors have to be taken into account: firstly, it is not necessarily ideal to be aiming at an enormous protein yield because overproduction of membrane proteins has been shown to destabilise the bacterial membrane leading to toxicity. Second, greater membrane protein yield also does not necessarily correlate with better activity, and the best expression conditions should always take into account the maintenance of protein activity. It is therefore recommended to aim for medium expression yield and always complement with activity tests to ensure that the condition(s) found are optimum for both protein expression and functionality.

\subsubsection{Choosing expression plasmids.}


Finding the right expression plasmid is the first step to ensure expression and stability of the protein. The plasmid chosen should consider the type of promoter used, the nature of the tag, the position of the tag and expression levels.

The T7 promoter offers great constitutive expression for most proteins but can be detrimental for membrane proteins. Therefore, other promoters have been developed, which can control more tightly the time of induction with appropriate inducers, such as T7lac, ptac promoter, arabinose or tetracycline promoters. These allow the production of MPs at a chosen time with fine tuning of expression, particularly useful if the MP is slightly toxic for bacterial membranes. (Table 2 for summary and for more information see reference (20)).

When choosing a tag, the topology of the target membrane protein has to be considered (6). Histidine tags (at least $6 \mathrm{x}$ and up to 10-12x depending on the target protein) have historically been used and led to much success because they are small tags and the purification procedure is easy. Unfortunately, charged tag such as histidine tags interfere with the bacterial folding machinery and thus with the protein topology, potentially leading to a misfolded protein. Therefore, while a charged tag is acceptable for membrane proteins which termini to be tagged is predicted in the cytoplasm, it is not recommended when present in the periplasm. In such case, an alternative strategy is to add a periplasmic targeting sequence prior to the tag, such as pelB, and add a large soluble protein after the tag, such as MBP (maltose binding protein). This has been a successful strategy for some proteins, such as NupC (21). Alternatively, a more neutral tag can be used such as StreptagII (IBA Lifesciences) or Flag tag (22). A further drawback of using His-tag for membrane proteins is the copurification of the target protein with the native E. coli membrane protein AcrB. Indeed, AcrB possesses a histidine cluster that binds naturally to nickel and cobalt resin, leading to contaminated purifications (23). $\triangle \mathrm{AcrB} C 41$ and $\mathrm{C} 43$ strains have been developed by a few groups, such as Martin Pos' group, to overcome this issue, and we are generating improved E. coli strains with a modified AcrB (Harborne \& Goldman, unpublished). A variety of other tags are also available. Table 3 gives a non-exhaustive overview of some protein tags successfully used in membrane protein purification studies. A combination of tags, such as a fluorescent tag (GFP) and purification tag can also be used 
to facilitate expression tests. Finally, it should be remembered that tags can influence the expression and the function of proteins. Therefore, when choosing the tag, both $\mathrm{N}$-terminal and C-terminal positions should be tested.

Ideally, the tag will be removed after purification to avoid interference with the structure and function. This can be efficiently achieved by introducing a protease cleavage site between the target protein and the tag. Not only will these avoid the presence of extra sequence for crystallisation studies, but the protease cleavage site also contributes as a spacer between the membrane protein and the tag, which can be essential if the $\mathrm{N}$ - or C-terminus is crucial for protein activity. TEV and HRV proteases have both been used successfully in membrane protein purification. While TEV works best at room temperature, HRV has the advantage that it is still functional at $4^{\circ} \mathrm{C}$, which is an asset for membrane proteins usually unstable at room temperature. Both TEV and HRV are commercially available or can be expressed and purified in house, which is more cost effective if large amounts are to be used. Other proteases are also available and their optimum working conditions (temperature, detergents, digestion times etc.) described (24).

As explained above, there are a number of plasmids, promoters and tags which are available to choose from for screening the best expression conditions. In our laboratory, we have observed that extraneous sequences are often detrimental for membrane protein topologies. Therefore, we recommend using classical cloning using restriction sites or PCR cloning, rather than other cloning strategies that often add additional DNA sequence to the open reading frame. This will minimise the probability of affecting either the structure of the function of the target membrane protein.

Once these choices of promoter, nature and position of tags and protease have been made, the following conditions can be tested for optimum expression.

\subsubsection{Host strain, media and temperature screen}


Following the careful design of a construct, the next steps are finding the right conditions for expression considering hosts, media and temperature. BL21(DE3)Gold is the common strain for testing expression of membrane proteins. However, testing a range of other strains is important to ensure that the best strain is used for the target protein. C41(DE3) and C43(DE3) strains have been specifically developed to increase expression of membrane proteins by lowering the transcription of mRNA when expressing toxic membrane proteins $(\mathbf{2 5 , 2 6 )}$. Lemo21(DE3), on the other hand, utilizes the co-expression of lysozyme, a T7 RNA polymerase inhibitor, to tune the transcription rate $(27,28)$.

In our hands, BL21(DE3)Star containing pRARE2 has proven to be the most successful in producing many membrane proteins, by providing tRNAs which are endogenously in low quantity in E. coli (19). Therefore, the small screen described below is mostly performed with 4 strains: C41(DE3), C43(DE3), BL21(DE3)Gold, BL21(DE3)Star.

\subsection{Quick Screening for expression conditions}

It seems intuitive that LB would be best expression medium because it is the most commonly used media for growing bacteria. However, some membrane proteins require slow expression for a longer time or fast expression for a shorter period of time. Hence other media such as M9 (minimal media) and SB (rich media) should also be tested. The paragraph below describes a small-scale experiment in the four bacterial strains described above, in 3 different media (M9, LB, SB) induced either with IPTG or by autoinduction. Autoinduction is another way to induce T7lac promoters and takes advantage of the diauxic shift in E. coli that naturally occurs upon glucose starvation during overnight cultures (29). Temperature is not described as a potential variable but can also be varied from $16^{\circ} \mathrm{C}, 25^{\circ} \mathrm{C}$ or $37^{\circ} \mathrm{C}$. The protocol below is a quick way to test various strains and growth conditions. It does not require complicated equipment or solutions and is therefore a simple method to quickly explore the best expression conditions.

\subsubsection{Small scale screen for growing conditions}


1. Freshly transform E. coli strains BL21-Gold(DE3), BL21 Star ${ }^{\mathrm{TM}}$ (DE3), C41(DE3) and C43(DE3) with a vector construct encoding an affinity-tagged ORF of the target protein.

2. Inoculate one $50 \mathrm{~mL}$ falcon tube with $10 \mathrm{~mL} \mathrm{LB}$ media + antibiotic and a single colony from the above transformants. Incubate overnight at $37^{\circ} \mathrm{C}$ in a shaker with rotation at $200 \mathrm{rpm}$. Ideally, if possible tilt the tubes slightly to prevent cell clumping.

3. Early the following morning, use $15 \mu \mathrm{L}$ of overnight cultures to inoculate $3 \mathrm{~mL}$ of either $\mathrm{LB}$, $\mathrm{M} 9, \mathrm{SB}, \mathrm{M} 9_{\text {auto }}, \mathrm{LB}_{\text {auto }}$ and $\mathrm{SB}_{\text {auto }}$ in $15 \mathrm{~mL}$ falcon tubes.

4. Grow the 3 autoinduction cultures for $24 \mathrm{~h}$ at $37^{\circ} \mathrm{C}$ with shaking at $200 \mathrm{rpm}$ (M9) auto, $\mathrm{LB}_{\text {auto }}$ and $\mathrm{SB}_{\text {auto }}$ ).

5. Grow the three additional tubes (LB, M9 and SB) for about $2 \mathrm{~h}$ at $37^{\circ} \mathrm{C}$ or until OD600nm reaches $0.5-0.8$. Add $0.5 \mathrm{mM}$ IPTG and grow the culture for a further $3 \mathrm{~h}-16 \mathrm{~h}$ at the desired temperature $\left(16^{\circ}, 25^{\circ}\right.$ or $\left.37^{\circ} \mathrm{C}\right)$. The commonly tested conditions is $3 \mathrm{H}$ induction at $37 \mathrm{C}$.

4. Transfer aliquots of $1 \mathrm{~mL}$ of culture into a $1.5 \mathrm{~mL}$ Eppendorf tube. Pellet the cells by centrifugation at $14,000 \mathrm{~g}_{\mathrm{av}}$ for $10 \mathrm{~min}$ at $4^{\circ} \mathrm{C}$.

5. Discard the supernatant.

6. $\quad$ Freeze the cell pellets at $-80^{\circ} \mathrm{C}$.

\subsubsection{Dot blots}

1. Add $100 \mu \mathrm{L}$ cell lysis reagent per tube and resuspend the cell pellet thoroughly. Incubate at $1,000 \mathrm{rpm}$ for $30 \mathrm{~min}$ at room temperature, on a plate shaker if possible.

2. Take duplicate $5 \mu \mathrm{L}$ samples for assay of protein concentration by the bicinchoninic acid (BCA) assay.

3. Mix cell lysate with $1 \mathrm{X}$ denaturing solution for dot blotting, incubate for $1 \mathrm{~h}$ at room temperature and then spot $3 \mu \mathrm{L}$ samples (equivalent of $5 \mu \mathrm{g}$ ) onto nitrocellulose membrane.

4. Incubate with blocking buffer for $1 \mathrm{~h}$ at room temperature or in a cold-room overnight.

5. Proceed with classical western blotting using the appropriate antibody against the membrane 
protein tag.

\subsection{Scaling up MP production}

\subsubsection{Scaling up Membrane preparations}

Once the expression conditions have been optimised (plasmids, strain and media), the culture can be scaled up using shaker flasks or a fermenter (19). Fermenters are rarely available in laboratories that do not typically overexpress proteins for structural biology. Therefore, we describe here upscaling with shaker flasks with IPTG induction. The procedure would be similar for autoinduction, except that an autoinduction protocol would be followed.

1. Freshly transform the E. coli strain identified in small scale expression as the best-expressing strain. Streak $10 \mu \mathrm{L}$ of the transformed cells onto LB-agar plate with selective antibiotic to ensure the growth of isolated colonies. Allow colonies to form overnight $(\mathrm{O} / \mathrm{N})$.

2. Prepare the starting culture by inoculating one colony in $50 \mathrm{~mL}$ LB with selective antibiotic and incubate the culture at $37^{\circ} \mathrm{C}$ with vigorous shaking in a baffled flask $\mathrm{O} / \mathrm{N}$.

3. The next day, measure $\mathrm{OD}_{600 \mathrm{~nm}}$ of the culture. Calculate the volume needed from the preculture to inoculate a prewarmed flask containing $500 \mathrm{~mL}$ of the chosen medium (selected in small scale assays) at a final $\mathrm{OD}_{600 \mathrm{~nm}}$ of 0.1 .

4. Incubate the culture at $37^{\circ} \mathrm{C}$ with shaking at $200 \mathrm{rpm}$ and monitor $\mathrm{OD}_{600 \mathrm{~mm}}$ every $30 \mathrm{~min}$ until it reaches $0.6-0.8$. This takes about $90 \mathrm{~min}$ or more depending on the media.

5. Add IPTG for induction to a final concentration of $0.5 \mathrm{mM}$ and incubate again at the identified optimum temperature with vigorous shaking for optimum time (temperature and time of induction would have been identified in small scale experiments)

6. Pellet cells by centrifugation at $6,000-9,000 \mathrm{x} g$ for 30 min at $4^{\circ} \mathrm{C}$ (typically $9,000 \mathrm{x} g$ would give better results, but the minimum speed is $6,000 \mathrm{x} g$ to be able to pellet enough cells). 
7. Discard supernatant and resuspend the pellet in cold Resuspension buffer ( $1 \mathrm{~g} / 6 \mathrm{~mL})$, Supplemented with protease inhibitors if necessary. Homogenize the cell suspension with a Dounce homogenizer or filter the cell suspension through $40 \mu \mathrm{m}$ nylon cell strainer.

8. Lyse cells with high pressure using a Cell disruptor (Constant Systems) operating at 30,000$40,000 \mathrm{psi}$ at $4^{\circ} \mathrm{C}$ for $5 \mathrm{~min}$. Alternatively, if no cell disruptor is available, use higher volumes of lysis buffer described in small scale preparation. Sonicators are not recommended as they usually denature the membrane protein and lead to precipitation.

9. Immediately perform medium-speed centrifugation at $4^{\circ} \mathrm{C}$ with a speed of $25,000 \mathrm{x} g$ for 30 min to remove cell debris and inclusion bodies.

10. Collect supernatant. Pellet membrane by ultracentrifugation at $4^{\circ} \mathrm{C}, 100,000 \mathrm{x} g$ for $2 \mathrm{~h}$.

11. Discard supernatant. Resuspend the pelleted membranes in minimal volume of Resuspension buffer (usually 1-2 mL) and homogenise with a Dounce homogenizer.

12. Determine total protein concentration via BCA assay (Pierce), because it is less susceptible to interference by lipids and detergent.

13. Snap freeze the prepared membrane fraction in aliquots of $30 \mathrm{mg} / \mathrm{mL}$ in resuspension buffer in liquid nitrogen and store at $-80^{\circ} \mathrm{C}$.

\subsubsection{Detergent screen}

For labs that do not necessarily have complex systems such as pre-packed columns and HPLC, we have found that batch purification of His-tagged membrane proteins was efficient and reproducible.

1. Thaw membranes on ice. Add various amounts of detergents to test and dilute in Solubilisation buffer to a final volume of $1-5 \mathrm{mg} / \mathrm{mL}$. Conditions tested usually range from $0.1 \%, 0.5 \%, 1 \%, 1.5 \%$, and $2 \%$.

2. Incubate for $1 \mathrm{~h}$ at $4^{\circ} \mathrm{C}$ with gentle rotation. 
3. Transfer $10 \mu \mathrm{L}$ in a new tube and add SDS sample buffer. Label as "Total "

4. Transfer the rest of the sample in an appropriate Eppendorf tube for centrifugation at 100,000x $g$ for $1 \mathrm{~h}$. This will remove any membranes that have not been solubilised.

5. Transfer supernatant in a fresh $1.5 \mathrm{~mL}$ tube. Remove $10 \mu \mathrm{L}$ and add Sample Buffer. Label as "Supernatant". This will correspond to the solubilised fraction.

6. If required, thoroughly resuspend pellet in the same volume as the supernatant. Remove 10 $\mu \mathrm{L}$ and add Sample Buffer. Label as "Pellet." This could be difficult as the pellet represents the insoluble fractions.

7. Load on the samples Total, Supernatant and pellet for SDS-PAGE. Proceed with classical western blotting.

The percentage of efficiency of solubilisation is determined by the ratio supernatant/total*100. The band intensities can be evaluated by densitometry using ImageJ (30).

\subsubsection{Scaling up membrane protein purification via batch IMAC}

Once the best solubilisation condition has been identified, membrane can be used for purification. The most common tag used is Histidine tag because it is convenient, efficient and quick. Therefore, although other tags are available, we have chosen to describe batch purification for His-tag proteins.

1. Solubilise membranes as described above with conditions identified as optimum.

2. Remove the insoluble fraction by centrifugation at $100,000 \mathrm{x} g$ at $4^{\circ} \mathrm{C}$ for $45 \mathrm{~min}$.

3. While membranes are being centrifuged, transfer $0.5 \mathrm{~mL}$ of washed IMAC agarose beads to a 50$\mathrm{mL}$ centrifuge tube, according to the manufacturer's instructions. This should be sufficient to purify proteins from $500 \mathrm{mg}$ of membranes, but this could be adjusted depending on the expression level of the protein. 
4. Transfer the supernatant from the centrifuged solubilisation onto the prewashed IMAC resin.

5. Incubate the $50 \mathrm{~mL}$ tube containing the resin and solubilised membranes for $2 \mathrm{~h}$ to overnight at $4^{\circ} \mathrm{C}$ with gentle agitation, using a rotary mixer.

6. Decant the resin into an empty gravity flow column and collect the flow-through (for analysis by SDS-PAGE).

7. Wash the resin with 10 column volumes of solubilization buffer. Collect the wash for analysis by SDS-PAGE.

8. Elute with 1-column volume of elution buffer. Collect the fraction. Repeat the step 10 times to achieve a 10 -column volume elution. Fractions can be stored at $4^{\circ} \mathrm{C}$ for up to a week depending on the protein.

9. Analyse $15 \mu \mathrm{L}$ of each fraction by SDS-PAGE.

\section{Membrane protein expression in insect cells}

\subsection{Cell culture}

The $S$. frugiperda cell lines (Sf 9 and $S f 21)$ and Trichoplusia $n i$ cell lines (Hi5) are the most commonly used insect cell lines for recombinant protein production using the baculovirus expression system. $S f 9$ and $S f 21$ are often used for virus production due to their capacity of producing infectious viral particles while Hi5 cells are optimized for protein production, especially for protein secretion (31,32). Here, we describe the procedure for culturing $S f 9$ cells and subsequent virus production and protein expression. Differences in culturing Hi5 cells are also described. SF900II medium is recommended for use for $S f 9$ and $S f 21$ cells, and we commonly use Express Five medium for culturing both $S f 9$ and Hi5 cells in our laboratory.

\subsubsection{Initiating insect cell culture from frozen stock}

When thawing insect cells from frozen stock to start a new culture, it is important to act fast under sterile conditions to minimize damage caused by osmotic shock and DMSO. As a general cell culture 
practice, everything should be sprayed with $70 \%$ ethanol before entering a laminar flow hood. This applies to all the procedures that require sterile cell culture work henceforth in this chapter.

1. Pre-heat water bath $\left(37^{\circ} \mathrm{C}\right)$ and incubate insect cell culture medium at $37 \mathrm{C}$ for $30 \mathrm{~min}$ before use. We do not add additives to the medium, such as serum and antibiotics as supplying antibiotics for daily cell maintenance can mask potential microorganism contamination.

2. Add $4 \mathrm{~mL}$ of pre-warmed medium to a $15-\mathrm{mL}$ sterile falcon tube and $2 \mathrm{~mL}$ of medium to a T-25 tissue culture flask.

3. Fetch one vial of frozen insect cells from liquid nitrogen cryo-storage and keep it in liquid nitrogen until the next step.

4. Quickly transfer the vial from liquid nitrogen to water bath. Flick the vial gently one or two times during the incubation until the cells are almost thawed (see Note 5).

5. Place the vial in a laminar flow hood.

6. Quickly pipette the cells to the falcon tube with medium prepared in Step 2. Count the cells and determine cell viability as described in section 4.1.2.2. Calculate the number of viable cells needed. A viable cell density at $2-5 \times 10^{4}$ cells $/ \mathrm{cm}^{2}$ is generally a good starting point for seeding. Here we use $1 \times 10^{6}$ viable cells per $25 \mathrm{~cm}^{2}$ flask as an example.

7. Pellet the cells gently by centrifuging at $100 \times \mathrm{g}$, for $5 \mathrm{~min}$ at room temperature (RT).

8. Under sterile conditions, discard the supernatant and resuspend the cell pellet gently with $2 \mathrm{~mL}$ of medium. Transfer the resuspended cells to the pre-wetted T-25 flask from Step 2.

9. Transfer the flask to a $27^{\circ} \mathrm{C}$ incubator and incubate until the cells grow to a monolayer with $80 \%$ confluency. Cell growth should be monitored daily. Replace the conditioned medium with fresh insect cell growth medium every 2 days if they grow slowly.

10. Passage the cells when they are $80 \%-90 \%$ confluent as described in section 4.1.2. 
11. Prepare cell frozen stocks after 2-3 passages for future use as described in section 4.1.3.

\subsubsection{Cell maintenance and Cell counting}

All the commonly used insect cell lines can be cultured either in adherent flasks or be adapted to suspension culture upon being thawed. We recommend starting new cultures in adherent flasks for all cell lines, especially for Hi5 cells, as they are prone to aggregate without adaptation to suspension culture.

\subsubsection{Cell maintenance}

\section{Cell maintenance in adherent culture}

1. Place a T-25 or T-75 flask with $80 \%$ to $90 \%$ cell confluency in a laminar flow hood.

2. Hold the flask at a $45^{\circ}$ angle and resuspend the cells with the conditioned medium by sloughing. To do this, stream the medium over the cell surface several times using a serological pipette tip (usually $5-\mathrm{mL}$ or $10-\mathrm{mL}$ ) to detach the cells.

3. Dilute the resuspended cells in a new flask with a ratio between 1:4 to 1:10, for example, adding $2 \mathrm{~mL}$ of resuspended cells from a T-75 flask to $8 \mathrm{~mL}$ of pre-warmed fresh growth medium in a new T-75 flask (see Note 6). Gently shake the flask horizontally to distribute the cells.

4. Place the flask in the incubator and monitor cell growth every $24 \mathrm{~h}$.

\section{Cell maintenance in suspension culture}

1. Maintain cells in a shaker flask shaking at $90 \mathrm{rpm}, 27^{\circ} \mathrm{C}$.

2. Place the flask in a laminar flow hood.

3. Take cell sample and count the cells and determine cell viability follow procedure in section 4.1.2.2. Cells should be at least $98 \%$ viable.

4. Dilute the cells to a final density of $0.5 \times 10^{6}$ cells $/ \mathrm{mL}$ with pre-warmed fresh medium for daily maintenance. The volume of culture in a shaker flask should be less than $25 \%$ of the 
flask capacity, for example, using a maximum volume of $60 \mathrm{~mL}$ in a $250-\mathrm{mL}$ shaker flask.

5. Place the shaker flask to temperature-controlled shaking incubator and monitor cell growth daily. Make sure the cell density does not exceed $3 \times 10^{6}$ cells $/ \mathrm{mL}$.

\section{Adaptation $S f 9, S f 21$ cells from adherent culture to suspension culture}

1. Place a T-75 flask with $80 \%$ to $90 \%$ cell confluency in a laminar flow hood.

2. Hold the flask at a $45^{\circ}$ angle and resuspend the cells with the conditioned medium by sloughing. Cells may attach tightly so that repeated sloughing is expected.

3. Count cells and determine cell viability.

4. Seed the cells to a $250-\mathrm{mL}$ shaker flask with a final cell density at $0.5-1 \times 10^{6}$ cells $/ \mathrm{mL}$. Dilute the cells with pre-warmed growth medium.

5. Incubate in a shaking incubator at $90 \mathrm{rpm}, 27^{\circ} \mathrm{C}$. Monitor cell density and viability daily.

6. Dilute cells when the cell density reaches $2 \times 10^{6}$ cells $/ \mathrm{mL}$.

7. Adaptation of the cells is achieved when the cells could keep doubling within $30 \mathrm{~h}$. Cell growth may be slow for several days when transferred from adherent culture to suspension culture before they could double properly.

\section{Adaptation Hi5 cells from adherent culture to suspension culture}

1. Place a T-75 flask with $80 \%$ to $90 \%$ cell confluency in a laminar flow hood.

2. Hold the flask at a $45^{\circ}$ angle and resuspend the cells with the conditioned medium by sloughing. Cells should be easily detached from the flask within 5 times of flushing by pipetting up and down.

3. Count cells and determine cell viability.

4. Seed the cells to a $250-\mathrm{mL}$ shaker flask with a final cell density at $0.5-1 \times 10^{6}$ cells $/ \mathrm{mL}$. Dilute the cells with pre-warmed growth medium no more than the volume of the cell suspension added. 
5. Add heparin to a final concentration of $10 \mathrm{U} / \mathrm{mL}$ (optional, see Note 7).

6. Incubate in a shaking incubator at $90 \mathrm{rpm}, 27^{\circ} \mathrm{C}$. Monitor cell density and viability daily.

7. Dilute cells when the cell density reaches $2 \times 10^{6}$ cells $/ \mathrm{mL}$ with serum-free medium supplemented with $10 \mathrm{U} / \mathrm{ml}$ heparin (optional).

8. Adaptation of the cells is achieved when the cells keep doubling within $24 \mathrm{~h}$. Heparin is no longer needed from this point onwards.

\subsubsection{Cell counting}

1. Place cell culture, sterile Eppendorf tubes, sterile pipette and serological pipette tips in a laminar flow hood.

2. With a serological pipette tip, take $100 \mu \mathrm{L}$ of cell sample from the suspension culture or resuspended cells to a sterile Eppendorf tube. If the culture is kept in the hood for an extended period of time (i.e. 2 min), the cells may settle. Resuspended the cells by shaking before taking samples.

3. Mix $10 \mu \mathrm{l}$ of the cell sample with $10 \mu \mathrm{L}$ of $0.4 \%$ trypan blue solution gently by pipetting up and down 5 times in an Eppendorf tube outside of the hood.

4. Proceed to cell counting depending on the availability of the lab apparatus as described below following Step 5 and 6 or Step 7-10.

\section{Cell counting with an automated cell counter}

5. Add $10 \mu \mathrm{L}$ of the cell-dye mixture to one side of a cell counting slice.

6. Count the cells and determine cell viability with an automated cell counter.

\section{Cell counting with a hematocytometer}

7. Wet tissue with $70 \%$ ethanol and clean the haematocytometer.

8. Add two small drops of water to the top and bottom sides of the chamber next to the grooves. Place the cover slip on top of the centre of the chamber. The slip should be firmly attached when the water repels out air between the slip and the chamber.

9. Add $10 \mu \mathrm{L}$ of the cell-dye mixture to one side of the chamber. 
10. With a $10 \times$ objective in an inverted microscope, count the cells within the central gridded big square (Fig. 1). More accurate cell count could be achieved by averaging cell counts from three different big squares and/or using a duplicate sample.

11. Viable cells should appear white while dead cells are stained blue if trypan blue is used. Multiply the viable cell count by $2 \times 10^{4}$ to calculate the number of cells per $\mathrm{mL}$ because of the $2 \mathrm{x}$ dilution factor. If trypan blue is not used, multiple the cell count by $10^{4}$.

\subsubsection{Freezing insect cells}

1. Maintain $250 \mathrm{~mL}$ of $S f 9$ cell culture in a 1-liter shaker flask, or another desired volume depending on need, within exponential growth phase, at $27^{\circ} \mathrm{C}$ with a shaking speed at 90 rpm. Make sure the cells have been doubling at least once every $30 \mathrm{~h}$ in the same flask and that cell viability is above $96 \%$.

2. Prepare $50 \mathrm{~mL}$ cell freezing medium under sterile condition for cryo-storage. For $S f 9$ and Sf 21 cells, the cell freezing medium should contain Xpress medium (or SF900II), 5\% FBS, and 10\% DMSO (see Note 8). For Hi5 cells, the cell freezing medium should contain $42.5 \%$ fresh Xpress medium, $42.5 \%$ conditioned medium, 5\% FBS, and $10 \%$ DMSO.

3. Follow Steps 5-10 under section 4.2.5 to prepare insect cell frozen stocks using the freezing medium prepared. For $S f 9$ and $S f 21$ cells, freeze $1 \times 10^{7}$ cells per vial whereas for Hi5 cells, freeze $3 \times 10^{6}$ cells per vial.

\subsection{Transfection of insect cells}

Since its initial development about 25 years ago $(33,34)$, the baculovirus expression vector system (BEVS) has been adapted to express numerous functional membrane proteins successfully. We use the Bac-to-Bac system to express membrane proteins. It involves a shuttle plasmid harbouring the gene of interest controlled by the polyhedrin promotor. Recombination of the protein gene with bacmid DNA is then achieved by transforming the plasmid into manufactured bacteria cell lines via a 
mini-AttTn7 site, for example EmBacY cells (see Note 9). The recombinant bacmid DNA is subsequently used for transfecting insect cells for baculovirus generation and amplification. In our laboratory, we use pFastbac vector with a polyhedrin promotor to express mammalian membrane proteins in $S f 9$ cells (see Note 10). In comparison to early promoters (Ie1), late promoters (polyhedrin, p10) initiate expression at a late stage of viral infection and usually behave better in protein over-production $(\mathbf{3 5 , 3 6 )}$.

\subsubsection{Recombinant Bacmid DNA preparation}

\section{Shuttle plasmid preparation}

1. Clone gene of interest (GOI) into the desired insect cell baculovirus transfer vector(s). Make sure the GOI is in the same coding frame as the promotor, tags or fusion proteins.

2. Transform into competent cells, for example DH5 $\alpha$ competent cells, and select colonies that harbour desired antibiotic resistance on LB agar plates depending on the shuttle vector used.

3. Inoculate a single colony into $3 \mathrm{~mL} \mathrm{LB}$ medium with antibiotics for plasmid isolation.

4. After mini-preparation of the shuttle plasmid, it is advisable to perform gene sequencing to verify the correct insertion of GOI.

\section{Bacmid DNA recombination}

5. Thaw competent DH10Bac E. coli cells, $100 \mu \mathrm{L}$ per plasmid, on ice in 14-mL roundbottom polypropylene tubes.

6. Incubate approximately $1 \mu \mathrm{g}$ of plasmid to $100 \mu \mathrm{L}$ of competent cells for $30 \mathrm{~min}$ on ice. Mix gently by tapping the bottom of the tube.

7. Heat shock the cells in pre-heated water bath at $42^{\circ} \mathrm{C}$ for $45 \mathrm{~s}$.

8. Place the tube back on ice and incubate for $2 \mathrm{~min}$.

9. Add $400 \mu \mathrm{L}$ of pre-warmed LB medium without antibiotics to the mixture and shakingincubate the mixture at $37^{\circ} \mathrm{C}$ overnight with a shaking speed at $220 \mathrm{rpm}$. For a harsh selection of successful transformants, add gentamycin to the mixture at a final 
concentration of $1 \mathrm{mg} / \mathrm{L}$. The addition of a low concentration of gentamicin could increase the number of white colonies in some cases.

10. The next day, prepare fresh Bacmid LB-agar plate for blue/white screening of colonies baring correct GOI insert (see Note 11) as described in section 2.6.

\section{Blue/white screening of successful transformants}

11. Perform serial dilution $(1: 10,1: 100,1: 1000)$ of the transformed cells after overnight incubation in LB medium. Place $100 \mu \mathrm{L}$ of the non-diluted and serially diluted cells to the pre-warmed Bacmid LB-agar plates and spread evenly.

12. Incubate the plates at $37^{\circ} \mathrm{C}$ for $24-36 \mathrm{~h}$. For the colonies to grow to the desired size and the colour to be distinguishable, a 30-h incubation is usually expected.

13. Pick single white colonies and inoculate $5 \mathrm{~mL}$ of LB medium for each colony picked, containing $50 \mathrm{mg} / \mathrm{L}$ kanamycin, $7 \mathrm{mg} / \mathrm{L}$ gentamicin and $10 \mathrm{mg} / \mathrm{L}$ tetracycline. To avoid picking up false positive clones, select only separate big white colonies. At the same time, re-streak the same selected colonies after inoculation to fresh Bacmid LB-agar plates

14. Incubate the mini-cultures with shaking at $250 \mathrm{rpm}$ and the re-streaked plates (if available) at $37^{\circ} \mathrm{C}$ overnight.

15. The next day, check the re-streaked plates and select two clones per construct that only grow white colonies for DNA isolation in the following steps.

\section{Bacmid isolation}

16. Pellet cells by centrifuging at $4^{\circ} \mathrm{C}, 2900 \mathrm{rpm}$ for $10 \mathrm{~min}$.

17. Remove supernatant and resuspend the cell pellets with $300 \mu \mathrm{L}$ of Bacmid cell resuspension buffer by gently pipetting up and down.

18. Transfer the homogeneously resuspended cells to a 1.5-mL Eppendorf tube.

19. Mix the resuspended cells with $300 \mu \mathrm{L}$ of Bacmid cell lysis buffer gently by end-to-end incubation. Inverting the tubes 5-10 times is usually sufficient.

20. Incubate at RT for 2-4 min. 
21. Add $300 \mu \mathrm{L}$ of Bacmid cell neutralization buffer to the samples and homogenize by endto-end incubation. Inverting the tubes 10 times is usually sufficient.

22. Centrifuge at $4^{\circ} \mathrm{C}, 15,000 \mathrm{x} g$ for $10 \mathrm{~min}$.

23. Transfer the supernatant to fresh Eppendorf tubes and centrifuge again with the same setting to pelleting any residual precipitated material.

24. Transfer the supernatant to fresh Eppendorf tubes and add $700 \mu \mathrm{L}$ of isopropanol to precipitate DNA. Gently mix by end-to-end incubation by inverting the tube for around 20 times until homogeneous.

25. Centrifuge to pellet precipitated DNA at $4^{\circ} \mathrm{C}, 15,000 \mathrm{x} g$ for $10 \mathrm{~min}$.

26. With a 1-mL pipette tip, carefully aspirate off the supernatant without disturbing DNA pellet at the bottom of each tube.

27. Add $200 \mu \mathrm{L}$ of $70 \%$ ethanol from one side of the tube gently.

28. Centrifuge at $4^{\circ} \mathrm{C}, 15,000 \mathrm{x} g$ for $10 \mathrm{~min}$.

29. Remove supernatant and add another $50 \mu \mathrm{L}$ of $70 \%$ ethanol from one side of the tube gently.

30. Centrifuge again at $4^{\circ} \mathrm{C}, 15,000 \mathrm{x} g$ for $5 \mathrm{~min}$.

31. Proceed to insect cell transfection or store the precipitated DNA at $-20^{\circ} \mathrm{C}$ until transfection.

\subsubsection{Transfection of insect cells with Bacmid DNA}

In this section, the procedure for transfecting insect cells in a 6-well plate is described. The procedure could be easily scaled up or down depending on the desired experimental format.

1. In a laminar flow hood, prepare sterile Eppendorf tubes, pipettes, pre-warmed insect cell culture medium and pipette tips.

2. Place the Eppendorf tubes containing precipitated Bacmid DNAs in the hood after spraying with $70 \%$ ethanol.

3. Remove $30 \mu \mathrm{L}$ of ethanol in the Eppendorf tubes from Step 30 in section 4.2.1. 
4. Let the DNA pellet to dry with the lids open. This step usually takes around 5-10 min. Monitor the tubes from time to time to avoid over-drying. Otherwise the pellet will be hard to dissolve.

5. Add $30 \mu \mathrm{L}$ of $\mathrm{ddH}_{2} \mathrm{O}$ to dissolve the DNA pellet. Tap the tube to assist the dissolving process. Pipetting should be avoided as this could cause shearing of Bacmid DNA.

6. Count insect cells and determine cell viability as described in section 4.1.2.2. Use cells that are growing in the exponential phase.

7. Pre-wet a 6-well plate with $2 \mathrm{~mL}$ of medium per well and seed cells in the plate with 0.5 $1 \times 10^{6}$ cells/well. Top up medium to a final volume of $3 \mathrm{~mL}$ in each well.

8. Place the plate in a $27^{\circ} \mathrm{C}$ incubator. Allow the cells to attach for $30 \mathrm{~min}$ prior to transfection.

9. For each plasmid, add $20 \mu \mathrm{L}$ of the dissolved DNA solution to $200 \mu \mathrm{L}$ of serum free insect cell medium without antibiotics, SF900II medium in our case. Mix by gently inverting the tubes.

10. Add $10 \mu \mathrm{L}$ of Xtreme Gene HD to $100 \mu \mathrm{L}$ of serum free insect cell medium without antibiotics. Mix by gently inverting the tubes.

11. Take $200 \mu \mathrm{L}$ and $100 \mu \mathrm{L}$ of the mixed solutions from Step 9 and 10 , respectively and mix them together.

12. Invert the tube 5 times to homogenize the solution and incubate in the hood for $4 \mathrm{~min}$.

13. Place the cell-seeded plate back into the hood.

14. Add $150 \mu \mathrm{L}$ of the transfection mixture to each well drop by drop in a circular motion to cover the entire surface area. For each plasmid, duplicate is prepared by adding $150 \mu \mathrm{L}$ of the transfection mixture twice to two different wells.

15. Seal the plate with parafilm to avoid evaporation (optional), which is important for plates with a small surface area and culture volume, such as 24 -well and 48 -well plates.

16. Incubate the plate at $27^{\circ} \mathrm{C}$ for $48-72 \mathrm{~h}$. We commonly incubate the plate for $60 \mathrm{~h}$ and it works for all constructs we have tested. 
17. Harvest medium from each well separately, which contains P0 virus, with serological pipette tips into sterile opaque Falcon tubes. If no contamination occurs, medium from the wells transfected with the same clone can be combined. If opaque Falcon tubes are not available, similar effect could be achieved by rapping Falcon tubes with foil.

18. Store $\mathrm{P} 0$ virus at $4^{\circ} \mathrm{C}$ protected from light.

19. Add $3 \mathrm{~mL}$ of pre-warmed medium to each well after harvesting.

20. Incubate the plate for another 3 days at $27^{\circ} \mathrm{C}$ to allow protein expression (optional).

21. Collect cells by sloughing using $500 \mu \mathrm{L}$ of ice-cold Insect cell resuspension buffer and spin down the cells at $1500 \times g$ for $5 \mathrm{~min}$. Discard the supernatant and freeze the pellet at $-20^{\circ} \mathrm{C}$.

22. Lyse the cells and analyse protein expression according steps 7 and 8 in section 4.3.2.

\subsubsection{Virus titration (plaque assay)}

Before virus amplification, it is a standard procedure to first determine the viral titre. Remeasuring viral titre is also recommended when recombinant virus is stored for an extended period of time (i.e. 2 months) at $4^{\circ} \mathrm{C}$.

1. Count insect cells and determine cell viability as described in section 4.1.2.2. Use cells that are growing at the exponential phase.

2. Place two 6-well plates in a laminar flow hood.

3. Pre-wet 6-well plates with $2 \mathrm{~mL}$ of medium per well and seed cells in the plate with $1 \times$ $10^{6}$ cells/well.

4. Place the plates in a $27^{\circ} \mathrm{C}$ incubator. Allow the cells to attach for $30 \mathrm{~min}$.

5. Liquify $4 \%$ agarose gel by incubating in a $70^{\circ} \mathrm{C}$ water bath.

6. Pre-warm $1.3 \times$ Sf-900 medium and a $50-\mathrm{mL}$ Falcon tube in a $37^{\circ} \mathrm{C}$ water bath.

7. After the cells adhere to the plate surface after step 3, place the plates in the hood with the P0 virus from step 17 in section 4.2.2. 
8. Prepared 10-fold serial dilutions of the virus from $10^{3}$ to $10^{8}$ dilutions with serum-free Sf900 II medium.

9. Discard supernatant from each well and add $1 \mathrm{~mL}$ of the diluted virus to the wells. Label the wells accordingly. Perform duplicates for more accurate calculation.

10. Incubate the plates at $27^{\circ} \mathrm{C}$ for $1 \mathrm{~h}$.

11. Place the pre-warmed sterile Falcon tube, medium and liquified agarose from step 6 in a laminar flow hood.

12. Quickly mix $30 \mathrm{~mL}$ of medium and $10 \mathrm{~mL}$ of $4 \%$ agarose in the Falcon tube and return to $37^{\circ} \mathrm{C}$ water bath until use.

13. After incubating the cells with virus, place the plates in the hood with the prepared agarose mixture.

14. Discard the supernatant from each well and quickly add $2 \mathrm{~mL}$ of the agarose mixture to the wells.

15. Keep the plates in the hood until the gel solidify.

16. Incubate the plates at $27^{\circ} \mathrm{C}$.

17. Monitor plaque formation daily and count the number of plaques. Incubation is done when the number of plaques remain the same for two days. This usually takes 4-10 days.

18. Calculate the viral titre.

$$
\mathrm{pfu} / \mathrm{mL}(\text { original })=\text { averaged number of plaques } / 1 \mathrm{~mL} \times \text { dilution factor }
$$

\subsubsection{Virus amplification}

Amplification of virus stocks can be performed using either suspension or adherent culture. We recommend using adherent culture for better virus quality (32). Here the procedure for amplifying virus using both methods is described. The multiplicity of infection (MOI) needs to be empirically determined for each construct and cell lines to be used. The optimal MOI can be different for different proteins. In our laboratory, we find that infecting a culture with the amount of virus or baculovirusinfected insect cells (BIIC, see section 4.2.5 for details) that allows the cells to double only once $24 \mathrm{~h}$ 
post-infection generally gives good expression results. The corresponding MOI for the construct could then be used for future infections. The procedure for titrating the virus for optimal protein expression is detailed in section 4.3.2.

\section{Virus amplification in adherent culture}

1. Prepare $80-90 \%$ confluent $S f 9$ culture in T-75 flasks following procedure in section 4.1.2.

2. Infect cells with P0 virus at an MOI of 0.01 to 0.1 . The amount of virus to use needs to be calculated based on the viral titre for each batch of virus generated.

$$
\text { Required virus }(\mathrm{mL})=\operatorname{MOI}\left(\frac{\mathrm{pfu}}{\mathrm{cell}}\right) \times \text { number of cells } / \text { viral titer }\left(\frac{\mathrm{pfu}}{\mathrm{mL}}\right)
$$

3. Harvest conditioned medium $48-60 \mathrm{~h}$ post-infection which contains P1 virus.

4. Determine viral titre by plaque assay as described in section 4.2.3.

5. Store $\mathrm{P} 1$ virus at $4^{\circ} \mathrm{C}$ protected from light.

\section{Virus amplification in suspension culture}

1. Maintain $S f 9$ cell culture at exponential phase following procedure in section 4.1 Make sure cells have been dividing at least twice in the same flask and dilute cells to $5 \times 10^{5}$ cells $/ \mathrm{mL}$ on the day of infection.

2. Infect cells with P0 virus at an MOI of 0.01 to 0.1 .

3. Harvest conditioned medium $48-60 \mathrm{~h}$ post-infection by centrifuging at $100 \times \mathrm{g}, 5 \mathrm{~min}$ to pellet the cells.

4. Save supernatant and this contains P1 virus.

5. Determine viral titre by plaque assay as described in section 4.2.3.

6. Store $\mathrm{P} 1$ virus at $4^{\circ} \mathrm{C}$ protected from light. 


\subsubsection{Using the titerless infected-cell preservation and scale-up (TIPS) method for virus storage and alterative infection}

When stored at $4^{\circ} \mathrm{C}$, baculovirus may lose its titre gradually and the stability varies depending on a number of factors, including the size of the inserted fragment(s), light protection, storage temperature and the addition of additives (37). Hence, some stored virus samples are stable for years while others become non-infectious within months. The titre of virus from separate batches should all be determined and for virus that has been stored for a long time (e.g. $\geq 2$ months), its activity should be re-assessed. To overcome this problem, in our laboratory we use BIIC to store baculovirus, which is adapted from the TIPS method (38). The resulting BIIC could be used for virus amplification as well as insect cell infection for large-scale protein expression (see Note 12).

1. Maintain $250 \mathrm{~mL}$ of $S f 9$ cell culture in a 1-liter shaker flask in the exponential growth phase, at $27^{\circ} \mathrm{C}$ with a shaking speed at $90 \mathrm{rpm}$. Make sure the cells have been doubling at least once within $30 \mathrm{~h}$ in the same flask and the cell viability is above $96 \%$.

2. Add an optimal amount of virus, pre-determined to allow the cells to double only once 24 h post-infection, to the $250 \mathrm{~mL}$ cell culture at $1 \times 10^{6}$ cells $/ \mathrm{mL}$.

3. On the day of proliferation arrest, prepare $50 \mathrm{~mL}$ BIIC freezing medium under sterile conditions for cryo-storage, which contains Xpress medium, 5\% FBS, and 10\% DMSO (see Note 8).

4. Take $100 \mu \mathrm{L}$ of cell sample for infection assessment. This should contain $2 \times 10^{5}$ cells if the culture has doubled just once.

5. Gently pellet BIIC by centrifuging at $100 \times g$ for $5-10 \mathrm{~min}$ at room temperature (RT).

6. In the meanwhile, prepare 50 sterile cryovials with proper labelling under the laminar flow hood.

7. Remove supernatant and resuspend the cells in BIIC freezing medium. 
8. Immediately aliquot the resuspended cells at $1 \mathrm{~mL} / \mathrm{vial}$ into the cryovials so that each cryo-vial contains $1 \times 10^{7}$ cells.

9. Without delay, transfer the vials to pre-cooled isopropanol freezing apparatus (Mr. Frosty) and place the apparatus at $-80^{\circ} \mathrm{C}$ for $24-48 \mathrm{~h}$ (see Note 13).

10. Place the vials in liquid nitrogen for long-term storage.

11. Assess the cell sample from Step 4 by resuspending it in $150 \mu \mathrm{L}$ of Insect cell resuspension buffer supplemented with $50 \mu \mathrm{L}$ of $4 \times$ SDS loading dye.

12. Analyse protein expression by SDS PAGE (in-gel fluorescence) and Western blot (see Notes 14 and 15).

\subsection{Optimization of protein expression and membrane purification}

\subsubsection{Finding the right construct}

This procedure is used to screen constructs for optimal membrane protein production and can be adapted to screen different media and cell lines when available. Baculovirus has been generated at this stage. The cell culture technique and the procedure for transfecting insect cells with recombinant bacmid are not described here because they are provided in detail in the Invitrogen manufacturer's instructions.

1. Place a deep 24-well plate in a laminar flow hood.

2. Add $3 \mathrm{~mL}$ of maintained $S f 9$ cells during exponential growth phase to each well at a density of $1 \times 10^{6}$ cells $/ \mathrm{mL}$.

3. Add $100 \mu \mathrm{L}$ of virus for each construct to each well.

4. Seal the plate with a gas permeable seal and place it on a sticky mat in temperaturecontrolled shaker.

5. Incubate the plate at $27^{\circ} \mathrm{C}$ with shaking at $250 \mathrm{rpm}$ for $72 \mathrm{~h}$. 
6. Take $10 \mu \mathrm{L}$ sample from each well on the day of harvesting and assess the primary expression and localization of the proteins bearing a GFP tag under fluorescent microscope (Fig. 2).

7. Pellet the rest of the cells by centrifuging at $1500 \times \mathrm{g}$ for $15 \mathrm{~min}$. The pellet can be frozen and stored at $-80^{\circ} \mathrm{C}$ if the experiment is not to be continued at this stage.

8. Lyse the pelleted cells by two freeze and thaw cycles. Freeze the cell pellet at $-80^{\circ} \mathrm{C}$ for half an hour and defrost the cells. Add $0.5 \mathrm{~mL}$ of Insect cell resuspension buffer. Repeat freeze and thaw step once.

9. Transfer the mixture to $1.5-\mathrm{mL}$ Eppendorf tubes. For each resuspended sample, separate them into two tubes with equal volume.

10. To one tube of each sample, add FC-12/CHS stock solution to a final concentration of $1 \%$ FC -12 and $0.2 \%$ CHS, To the other tube of the same sample, add DDM/CHS stock solution to the same final concentration (see Note 16).

11. Incubate the mixtures on a table-top incubator at $4^{\circ} \mathrm{C}$, shaking at $1,000 \mathrm{rpm}$ overnight.

12. Take $60 \mu \mathrm{L}$ sample from each tube for total protein analysis.

13. Spin sample at $4^{\circ} \mathrm{C}$ with a speed of $100,000 \mathrm{x} g$ for $45 \mathrm{~min}$ in an ultracentrifuge to pellet any insoluble materials.

14. Take $60 \mu \mathrm{L}$ sample from each tube without disturbing the pellet for solubilized protein analysis.

15. Prepared the samples for SDS PAGE (in-gel fluorescence) and western blot analysis (see Note 14).

16. Calculate the solubilization efficiency of the targeted protein in FC-12/CHS and DDM/CHS for each construct.

17. Determine the best construct to be taken forward. The construct should give the highest expression level of the target protein as well as the percentage of solubilized intact target protein from the total protein in DDM/CHS. 


\subsubsection{Finding the right expression condition - virus titration, expression time}

Once a suitable construct has been chosen to express the target protein, it is worthwhile to optimize the expression condition, such as the amount of virus for transfection and the expression time for maximal protein production. The MOI needed to transfect insect cells varies for different proteins. Hence the optimal MOI to use needs to be separately determined by screening using a deep 24-well plate.

1. Place a deep 24-well plate in a laminar flow hood.

2. Add $3 \mathrm{~mL}$ of maintained $S f 9$ cells during exponential growth phase to each well at a density of $1 \times 10^{6}$ cells $/ \mathrm{mL}$.

3. Add virus with different MOI from 2 to 20 , to each well.

4. Seal the plate with a gas permeable seal and place it on a sticky mat in temperaturecontrolled shaker.

5. Incubate the plate at $27^{\circ} \mathrm{C}$ with shaking at $250 \mathrm{rpm}$.

6. Take $200 \mu \mathrm{L}$ of sample from each well every $24 \mathrm{~h}$ for three days. Spin down the cells at $1500 \times \mathrm{g}$ for $5 \mathrm{~min}$. Discard the supernatant and freeze the pellet at $-20^{\circ} \mathrm{C}$.

7. Thaw the cell pellet and resuspend in $150 \mu \mathrm{L}$ of Insect cell resuspension buffer supplemented with $50 \mu \mathrm{L}$ of $4 \times$ SDS loading dye.

8. Analyse protein expression levels from all the samples by SDS PAGE (in-gel fluorescence) and western blot (see Note 14).

9. Determine the optimal MOI and the expression time. The chosen condition should give the maximal protein expression level.

\subsubsection{Small-scale expression}

1. Maintain $50 \mathrm{~mL}$ of $S f 9$ cell culture in a $250-\mathrm{mL}$ shaker flask within exponential growth phase, at $27^{\circ} \mathrm{C}$ with a shaking speed at $90 \mathrm{rpm}$. Make sure the cells have been doubling at 
least once within 24 hours in the same flask (see Note 17). Use trypan blue during cell counting to determine cell viability: viable cells should be more than $96 \%$ of the total number of cells.

2. Add optimal amount of virus, pre-determined as described in the previous section, to the $50 \mathrm{~mL}$ of cell culture at $1-2 \times 10^{6}$ cells $/ \mathrm{mL}$.

3. Harvest cells by centrifuging at $4^{\circ} \mathrm{C}, 1500 \times g$ for $15 \mathrm{~min}$ after incubation for the optimal expression time. Cell pellet can be flash frozen and store at $-80^{\circ} \mathrm{C}$ at this point.

4. Proceed to cell membrane preparation as described in section 4.3.4.

\subsubsection{Cell membrane preparation with sucrose cushion}

Solubilizing membrane proteins using detergents is a commonly used approach. However, it requires the use of a significant amount of detergent to solubilize membrane proteins after scaling up. Our adapted sucrose cushion membrane preparation method $(39,40)$ described below has shown success in isolating and concentrating detergent soluble membrane vesicles containing target proteins (see Note 18), which increases cost and time effectiveness (Fig. 3).

1. To a cell pellet from $50 \mathrm{~mL}$ culture, add $2 \mathrm{~mL}$ of ice-cold Insect cell resuspension buffer.

2. Resuspend the cell pellet and lyse the cells on ice using Dounce homogenizer for approximately 20 strokes.

3. Remove unbroken cells and genomic DNA by centrifuging at $4^{\circ} \mathrm{C}, 1,000 \mathrm{x} g$ for $10 \mathrm{~min}$.

4. Transfer supernatant to ultracentrifuge tubes $(10.4 \mathrm{~mL}$ capacity) and resuspend in approximately $6 \mathrm{~mL}$ of Sucrose buffer A.

5. Carefully add $1 \mathrm{~mL}$ of ice-cold Sucrose buffer B (see Note 18) to the bottom of each ultracentrifugation tube.

6. Centrifuge at $4^{\circ} \mathrm{C}, 38,500 \mathrm{rpm}$ for 90 min using a Beckman Ti70.1 rotor or equivalent.

7. Carefully withdraw $1 \mathrm{~mL}$ liquid from the bottom of each ultracentrifugation tube. 
8. Pour the rest of supernatant into clean containers for analysis.

9. Resuspend the pellet with $7 \mathrm{~mL}$ of ice-cold Sucrose buffer A using Dounce homogenizer and transfer the mixture to clean ultracentrifuge tubes.

10. Repeat Step 5-8.

11. Resuspend the cell pellet with $5 \mathrm{~mL}$ of Membrane resuspension buffer for analysis. This step can be eliminated in future attempts once the solubilization efficiency of this fraction has been tested.

12. The final $1 \mathrm{~mL}$ liquid samples taken from the bottom of each tube should contain mostly detergent soluable membrane vesicles.

13. Take $60 \mu \mathrm{L}$ from each sample collected and proceed to SDS PAGE analysis (in-gel fluorescence) and WB with desired antibody to detect the distribution of the target protein (see Note 14).

14. Determine total protein concentration by Bradford assay (41).

15. Snap freeze the prepared membrane fraction in liquid nitrogen and store at $-80^{\circ} \mathrm{C}$.

\subsubsection{Detergent screening}

We recommend using a large diversity of detergents with different properties depending on their charge, size and scaffold with or without the addition of lipids or their derivatives. As a starting point, it is worthwhile to try a set of detergents that have been successfully applied to solubilize membrane proteins for structural studies (42). We have a collection of 10 detergents for initial screening (Table 4) where FC-12 is included to be used as a positive control. In our laboratory, we found supplementing CHS to the detergents at a final concentration of $0.2 \%$ increases overall solubilization efficiency. Thaw prepared membrane sample on ice.

1. Dilute sample with Binding buffer to $200 \mu \mathrm{L}$ to a final protein concentration of $5 \mathrm{mg} / \mathrm{mL}$.

2. Add detergent stock to the diluted sample to a final concentration of $1 \%(2 \%$ for $\mathrm{OG})$. If needed, CHS should be added to a final concentration of $0.2 \%$. 
3. Mix and incubate the mixture by shaking at $4^{\circ} \mathrm{C}$, at 1,000 rpm overnight using a table-top incubator (see Note 19).

4. Take $60 \mu \mathrm{L}$ sample from the mixture before ultracentrifugation for total protein (TP) analysis.

5. Pellet insoluble fraction by ultracentrifugation at $4^{\circ} \mathrm{C}, 100,000 \mathrm{x} g$ for $45 \mathrm{~min}$ with an S100-AT3 rotor in a micro-ultracentrifuge (Sorval MX120+).

6. Take $60 \mu \mathrm{L}$ supernatant (SN) from each sample after ultracentrifugation without disturbing the pellet.

7. Assess the solubilization efficiency of the target membrane protein in the detergents tested by SDS PAGE (in-gel fluorescence) and western blot (Fig. 3).

8. Depending on the function of individual proteins, perform an activity assay to assess the functionality of the solubilized target protein.

\subsubsection{Large-scale membrane protein production}

Large-scale expression shall be carried out after expression condition optimization as described above. The following method is routinely used in our laboratory for large-scale membrane protein expression using $S f 9$ cells and cell membrane preparation. The method could be easily modified and scaled up if required.

1. Maintain $S f 9$ cell culture in $2 \mathrm{~L}$ shaker reagent bottles within exponential growth phase (1 litre maximum culture volume), at $27^{\circ} \mathrm{C}$ with a shaking speed at $120 \mathrm{rpm}$. Make sure the cell viability is above $96 \%$.

2. Infect cells at $1-2 \times 10^{6}$ cells $/ \mathrm{mL}$ with optimal amount of virus, pre-determined during optimization screening (see Note 12)

3. Harvest cells by centrifuging at $4^{\circ} \mathrm{C}, 1500 \times g$ for $15 \mathrm{~min}$. Cell pellet can be stored at $80^{\circ} \mathrm{C}$ if needed. 
4. To a cell pellet from 1-litre culture, add $75 \mathrm{~mL}$ of pre-cooled Sucrose buffer A supplemented with DNase $5 \mu \mathrm{L} / 1 \mathrm{~mL}$.

5. Resuspend the cells by pipetting up and down with a serological pipette. Filter the cell suspension through $40 \mu \mathrm{m}$ nylon cell strainer to make sure there is no cell pellet left in the mixture that could cause blockage during lysis in the next step.

6. Leave the cell suspension on ice for $10 \mathrm{~min}$.

7. Lyse cells with high pressure using Emulsiflex, operating at 10,000-12,000 psi for 5 min (see Note 20)

8. Immediately centrifuge the lysate at $4^{\circ} \mathrm{C}, 1000 \times g$ for $10 \mathrm{~min}$ to remove intact cells and nuclei.

9. Collect and transfer the supernatant to ultracentrifuge tubes, occupying approximately $60 \%$ tube capacity $(70 \mathrm{~mL})$.

10. Carefully add $4 \mathrm{~mL}$ of ice-cold Sucrose buffer B to the bottom of each ultracentrifugation tube.

11. Centrifuge at $4^{\circ} \mathrm{C}, 42,000 \mathrm{rpm}$ for 90 min using a Beckman Ti45 rotor.

12. Carefully withdraw $3.5 \mathrm{~mL}$ liquid from the bottom of each ultracentrifugation tube.

13. Pour the rest of supernatant to clean containers for analysis.

14. Resuspend the pellet with $45 \mathrm{~mL}$ of ice-cold Sucrose buffer A using a Dounce homogenizer and transfer the mixture to clean ultracentrifuge tubes.

15. Repeat Step 10-13.

16. The pellet can be discarded if analysis has been done in the small-scale expression test.

17. The final $3.5 \mathrm{~mL}$ liquid samples taken from the bottom of each tube should contain mostly detergent soluble membrane vesicles.

18. Take $60 \mu \mathrm{L}$ from each sample collected and proceed to SDS PAGE analysis (in-gel fluorescence) and western blot with desired antibody to detect the distribution of the target protein (see Note 14).

19. Determine total protein concentration by Bradford or BCA assay. 
20. Snap freeze the prepared membrane fraction in liquid nitrogen and store at $-80^{\circ} \mathrm{C}$.

21. Perform membrane solubilization with a total protein concentration at $5 \mathrm{mg} / \mathrm{mL}$ using the pre-determined detergent and lipid (if used) mixture, at $4^{\circ} \mathrm{C}$ with end-to-end rotation (see Note 21).

22. Ultracentrifuge to pellet insoluble fraction at $4^{\circ} \mathrm{C}, 38,500 \mathrm{rpm}$ for $45 \mathrm{~min}$ using a Beckman Ti70.1 rotor.

23. Transfer supernatant after ultracentrifugation to a clean container.

24. Assess solubilized target membrane protein by SDS PAGE (in-gel fluorescence) and WB (see Note 14).

25. Determine total protein concentration in the detergent-solubilized fraction by Bradford assay (41).

26. Proceed to protein purification in section 4.4.

\subsection{Purification of Membrane proteins by affinity chromatography}

4.4.1 His-tagged membrane proteins by immobilized metal affinity chromatography (IMAC)

This section describes the procedure to purify solubilized His-tagged membrane proteins using metal affinity chromatography. As mention above, the addition of CHS to detergents improves the solubilization efficiency for many membrane proteins in our laboratory; therefore, we use the combination of LMNG and CHS, as an example, in buffers for purifying a membrane protein that is solubilized using the same detergent and lipid mixture. The buffer composition and the choice and concentration of detergents should be adjusted as appropriate. All procedures are recommended to be done in cold, especially for temperature-sensitive unstable proteins. 
1. Equilibrate $1 \mathrm{~mL}$ of settled TALON metal affinity resin (see Note 22) with washing buffer A for the solubilized membrane protein sample from 1-litre culture. This is done by washing the beads 3 times with $10 \mathrm{~mL}$ of $\mathrm{ddH}_{2} \mathrm{O}$ (MilliQ) and 3 times with Washing buffer A. Each time gently invert the tubes to resuspend the beads and centrifuge at $800 \times$ $g, 2$ min for pelleting.

2. Dilute solubilized protein with modified Washing buffer A by excluding detergent, to bring down detergent concentration to $0.2 \%$ LMNG, $0.04 \%$ CHS.

3. Incubate the diluted protein sample with TALON resin $2-16 \mathrm{~h}$ in the cold room on a roller mixer (see Note 23).

4. After binding, pack the beads by gravity flow in a 20 -mL column and collect flow through (FT) for analysis (see Note 24).

5. Wash beads with 20 column volumes (CV) of Washing buffer $\mathrm{A}$ and another $20 \mathrm{CV}$ of Washing buffer B (see Note 25).

6. Without disturbing the beads, gently add $8 \mathrm{CV}$ Elution buffer dropwise to the beads to elute bound protein. Collect $0.5 \mathrm{~mL}$ of eluate each time (see Note 23).

7. Close the column outlet and carefully resuspend the beads in $1 \mathrm{~mL}$ of elution buffer. Incubate the mixture for $10 \mathrm{~min}$.

8. Open the column outlet and collect FT by gravity flow.

9. Repeat Step 7-8. Monitor $A_{280 n m}$ of the fractions using a Nanodrop until the signal drops to zero (see Note 26).

10. Measure $A_{280 \mathrm{~nm}}$ of the elution fractions (see Note 27) and assess protein purity from each fraction by SDS PAGE.

11. Pool the peak fractions.

12. Concentrate the combined eluate with a concentrator with an appropriate molecular weight cut-off (see Note 28).

13. Perform buffer exchange into Desalting buffer using a Bio-rad spin column (see Note 29). 
14. Determine the protein concentration of the final sample and take a small aliquot for SDS PAGE to assess the purity.

15. Perform secondary purification if necessary (see Note 30).

16. Check activity of the purified membrane protein by a suitable protein-specific assay (see Note 31).

\subsubsection{Purification of Flag-tagged membrane proteins by affinity chromatography}

This section describes the procedure to purify solubilized Flag-tagged membrane proteins using anti-Flag resin. Positive charges near the membrane on the outside of the cell has been reported to have a negative impact on membrane protein translocation (6). In contrast to the highly positively-charged His tag at lower $\mathrm{pH}$, Flag tag has a small negative charge, which could be a good alternative to the widely-used His tag (see Note 32). Using Flag tag for subsequent purification could also yield purer protein sample after elution due to the high binding specificity. The buffers used and all procedures should be done in cold as mentioned before in section 4.4.1.

1. Equilibrate $1 \mathrm{~mL}$ of settled anti-Flag resin with washing buffer $\mathrm{A}$ for the solubilized membrane protein sample from 1-litre culture (see Note 33). This is done by washing the beads 3 times with $10 \mathrm{~mL}$ of TBS and 3 times with $10 \mathrm{~mL}$ of Washing buffer A. Each time gently invert the tubes to resuspend the beads and centrifuge at $2000 \times g$, $45 \mathrm{~s}$ for pelleting. 
2. Dilute solubilized protein with modified Washing buffer A by excluding detergent, to bring down detergent concentration to $0.2 \%$ LMNG, $0.04 \%$ CHS.

3. Incubate the diluted protein sample with anti-Flag resin $4-16 \mathrm{~h}$ in the cold room on a roller mixer (see Note 23).

4. After binding, pack the beads by gravity flow in a $20-\mathrm{mL}$ column and collect flow through (FT) for analysis (see Note 24).

5. Wash beads with 20 column volumes (CV) of Washing buffer $\mathrm{A}$ and another $20 \mathrm{CV}$ of Desalting buffer (see Note 25).

6. Prepare Flag elution buffer containing $300 \mu \mathrm{g} / \mathrm{mL}$ poly-Flag peptide in Desalting buffer.

7. Without disturbing the beads, slowly add $4 \mathrm{CV}$ elution buffer dropwise to the beads to elute bound protein. Collect $0.5 \mathrm{~mL}$ of eluate each time (see Note 34).

8. Close the column outlet and add $1 \mathrm{~mL}$ of Flag elution buffer to the resin. Gently resuspend the resin with a pipette. Incubate for $10 \mathrm{~min}$. Collect eluate by gravity flow.

9. Repeat Step 8 for 4 times.

10. Follow Step 10-16 in section 4.4.1 and assess protein purity by SDS PAGE (Fig. 4).

11. Regenerate anti-Flag resin with Regeneration buffer and store the resin at $-20{ }^{\circ} \mathrm{C}$ in buffer containing 50\% glycerol or other conditions according to manufacturer's instruction for further usage. Freezing of the resin should be avoided. 


\section{Notes}

1. Auto-induction is primarily used as a quick screening method: because cells are induced during diauxic shift while growing, synchronisation of various cultures is not necessary as for IPTG induction. This allows more flexibility for induction experiments.

2. Speed up lactose dissolving by gently warming up the solution.

3. Solution containing guanidine can sometimes crystallise and therefore can be stored at $37^{\circ} \mathrm{C}$ instead.

4. Other possible detergents include MNG (maltose neopentyl glycols), GNG (glucose neopentylglycol) etc. (discussed in section 4.3.5).

5. Make sure the lower part of the vial is sufficiently immersed so that all cells are evenly warmed up. Cap of the vial should be kept above water to avoid contamination.

6. We do not add serum or antibiotics to the growth medium for cell maintenance. However, gentamycin and streptomycin could be added to the culture medium when scaling up for transfection as indicated in section 4.3 .

7. Adding heparin to prevent cell aggregation is optional. Adaptation of Hi5 cells to suspension culture in our laboratory worked fine without heparin. However, we observed that when first transferred to shaker flasks, the viability of cells grown without heparin was typically lower (92\%) than those grown with heparin (99\%). After a few passages, the cell viability will rise to $99 \%$.

8. The cell freezing medium should be prepared using fresh medium that the $S f 9$ cells have been adapted to.

9. As an alternative to the Bac-to-Bac transportation system for recombinant bacmid DNA generation, homologous recombination between transfer DNA and viral DNA in insect cells can also be used (43-47). The Bac-to-Bac system relies on engineered E. coli strains with autonomously replicating viral genome, encoded transposase and mini-Tn7 attachment site, where transposition occurs (48). In comparison to the generic transportation method, recombinant baculovirus generation using homologous recombination may be less efficient, 
but the resulting protein may be more stable through virus passaging due to the lack of bacterial replicon (49). Thus, the choice of appropriate baculovirus expression system depends on need and the availability of resources in the laboratory.

10. Other cells lines can also be employed for membrane protein expression, for example High Five cells from Trichoplusia ni, which often show high protein expression level. However different cell lines may produce inactive proteins through various mechanisms (18). The functionality of the expressed proteins needs to be determined along with its overall expression level for each protein and virus.

11. The correct insertion of the GOI in to the bacmid results in failure of lacZa peptide expression; therefore, desired colonies should appear white in comparison to the blue wildtype colonies.

12. Cells could also be infected using BIIC. The optimal amount of BIIC to use should be titrated empirically. The detailed procedure for BIIC preparation can be found in section 4.2.5.

13. If a "Mr. Frosty" freezing container is not available, the aliquoted cells can be placed at $-20^{\circ}$ $\mathrm{C}$ for $1 \mathrm{~h}$ followed by incubation at $-80^{\circ} \mathrm{C}$ for $24-48 \mathrm{~h}$.

14. To prepare membrane protein samples for SDS PAGE, the samples should not be boiled as this typically cause membrane proteins to aggregate. We often incubate the protein sample with SDS PAGE loading dye at room temperature for 10 min prior to loading. In this way, proteins that contain a GFP tag could be assessed by in-gel fluorescence after SDS PAGE. If the protein does not denature well under this condition, the samples could be incubated at a higher temperature, i.e. $37^{\circ} \mathrm{C}$.

15. Successfully infected cells should show expression of the target protein on the day of BIIC preparation. However, low expression level of the protein at this stage may be expected.

16. As a zwitterionic detergent, Fos-Choline 12 disrupts both inter- and intra- molecular proteinprotein interactions; therefore, it is harsher than most non-ionic detergents, for example, DDM, in solubilizing membrane proteins. We thus use FC-12 as a positive control to indicate the maximum amount of solubilised protein. Ideally, the yield of a membrane protein solubilized solubilised in DDM or another non-ionic detergent should be comparable to that 
in FC-12. In other words, one should be alarmed if a membrane protein can only be solubilized in FC-12.

17. Cells may need some time to adapt to a new flask so that they may not double properly within $30 \mathrm{~h}$ when first seeded to a new flask. To better assess the effect of virus infection, we typically allow the cells to double at least once in a culture flask before infection.

18. The concentration of sucrose in Sucrose buffer B should be tested and adjusted as appropriate for individual proteins from $0.75 \mathrm{M}$ to $1.2 \mathrm{M}(\mathbf{5 0 , 5 1 )}$. In our laboratory, $0.75 \mathrm{M}$ sucrose works well to isolate detergent soluble receptor tyrosine kinases.

19. We use a TS-100C (Biosan) table-top incubator for small samples in Eppendorf tubes. Alternatively, samples could be incubated by end-to-end rotation or in other suitable incubators.

20. An alternative approach to lyse the cells is using Dounce homogenizer. Insect cells should be efficiently lysed in 20 strokes.

21. To efficiently solubilize membrane proteins, a good ratio of detergent to total membrane should be obtained. The optimal total protein concentration to use for protein solubilization should be assessed for each protein. As a starting point, we recommend using a final protein concentration at $5 \mathrm{mg} / \mathrm{mL}$. However, $1-5 \mathrm{mg} / \mathrm{mL}$ protein concentration could be tested.

22. TALON metal affinity resin uses chelated cobalt to capture His-tagged proteins. In comparison to Ni affinity resin, TALON resin often shows improved selectivity towards Histagged proteins as a result of the spatial requirement that the structure of cobalt creates (52). In principal, $1 \mathrm{~mL}$ of settled TALON resin could bind 5-15 mg His-tagged protein. The binding capacity for proteins may be different under various buffer conditions; therefore, the amount of TALON resin to use for purification should be empirically determined to allow sufficient binding of the target protein with minimal non-specific binding.

23. The length of incubation for individual proteins may vary. Additionally, due to the presence of detergent micelles, binding of solubilized membrane protein to the resin may be slow. Prolonged incubation time is often expected and should be determined empirically. Similarly, 
dissociation of the bound proteins from the resin may also be slow. Incubate the resin with elution buffer for 5-10 min could increase the elution efficiency in step 6, section 4.4.1.

24. TALON resin can be pelleted by centrifuging at $4^{\circ} \mathrm{C}, 800 \times \mathrm{g}$ for $2 \mathrm{~min}$ in batch purification mode, while anti-Flag resin can be pelted by centrifugation at $4^{\circ} \mathrm{C}, 2,000 \mathrm{x} g$ for $45 \mathrm{~s}$. Remove the supernatant, transfer the pelleted resin and pack column by gravity flow.

25. Do not disturb the beads for optimal elution results.

26. By measuring $A_{280 n m}$ signal, we could monitor when the elution is complete as the signal drops to zero.

27. The extinction coefficient can be calculated from the protein sequences. This could be used when measuring protein concentration with Nanodrop. However, the presence of imidazole in the elution buffer causes show strong absorption at $280 \mathrm{~nm}$. When using elution buffer as blank for the measurement, the first elution fraction is likely to show abnormal absorption because there is a mixture of washing buffer and elution buffer in this fraction.

28. The size of detergent micelles varies due to their physical properties. For instance, DDM forms a micelle size of $60 \mathrm{kDa}$ while LMNG has a micelle size of $90 \mathrm{kDa}$ on average. Therefore, a centrifugal concentrator with a $100 \mathrm{kDa}$ cut-off is necessary to avoid accumulation of free detergent micelles. Since the overall size of the solubilized membrane protein is also increased due to the formation of protein-detergent micelle, membrane protein with a MW of $50 \mathrm{kDa}$ should still be retained.

29. Alternatively, dialysis could be performed. The eluate can be dialyzed against $500 \mathrm{~mL}$ of dialysis buffer twice, containing a low concentration of detergent above its critical micelle concentration (Dialysis sometimes is a better approach to remove imidazole or buffer exchange because of its slow exchange rate comparing to using desalting columns. When anti-Flag resin is used for purification, poly-Flag peptide $(2,864 \mathrm{Da})$ existing in the eluate needs to be removed either by dialysis or by using a desalting column.

30. As a secondary purification method or an approach to assess protein homogeneity and oligomeric state, size exclusion chromatography should be performed. For GFP-tagged 
membrane proteins, fluorescence-detection size exclusion chromatography could be carried out (53).

31. Methods for functional studies depend on the protein in question. Ligand binding assay can be performed if the protein has known binding partners, as measured by gel-shift, pull-down or proximity assays. For a receptor kinase, autophosphorylation assay is a logical choice. Commonly, the phosphorylation event could be measured by detecting radio-labelled phosphate $(\mathbf{5 4 , 5 5 )}$ or WB using specific anti-phospho-antibodies. For transporters, one approach is to reconstitute the detergent-solubilized membrane protein into proteoliposome and measure substrate flux (56).

32. Strep tag is another suitable small tag with a neutral isoelectric point (pI) to replace His tag (6). Strep tag has the capacity of binding to Streptavidin or its derivative, Strep-Tactin for purification. Twin-strep tag is often used instead of a single Strep tag for improved affinity. For strep-tagged protein purification, keeping $\mathrm{pH}$ above 7.5 is important for the binding and competitive elution is performed by eluting bound proteins with buffer containing $2-5 \mathrm{mM}$ desthiobiotin. Nonetheless, other tags could also be explored (57).

33. Anti-Flag resin generally binds at least $1 \mathrm{mg}$ of Flag-tagged protein per $1 \mathrm{~mL}$ of packed resin. The amount of resin to use depends on the overall expression level of the individual proteins.

34. The elution efficiency of Flag-tagged proteins with poly-Flag peptide is low. Incubating the poly-Flag peptide containing buffer with the beads for 10-30 min may be necessary in most of the cases for efficient elution.

\section{Acknowledgements}


Biotechnology and Biological Sciences Research Council (BBSRC, BB/M021610/1) to AG, https://www.bbsrc.ac.uk/; We would like to thank Steve Baldwin who is still inspiring for the membrane proteins field.

\section{References}

1. Wallin E, von Heijne G. (1998) Genome-wide analysis of integral membrane proteins from eubacterial, archaean, and eukaryotic organisms. Protein Sci 7(4):1029-1038.

doi:10.1002/pro.5560070420

2. Krogh A, Larsson B, von Heijne G, Sonnhammer ELL (2001) Predicting transmembrane protein topology with a hidden markov model: application to complete genomes11Edited by F. Cohen. J Mol Biol 305(3):567-580. doi:10.1006/jmbi.2000.4315

3. Rask-Andersen M, Almén MS, Schiöth HB (2011) Trends in the exploitation of novel drug targets. Nat Rev Drug Discov 10(8):579-590. doi:10.1038/nrd3478

4. White SH (2009) Biophysical dissection of membrane proteins. Nature 459(7245):344-346. doi:10.1038/nature08142

5. Bernaudat F, Frelet-Barrand A, Pochon N, Dementin S, Hivin P, et al. (2011) Heterologous expression of membrane proteins: choosing the appropriate host. PLoS One 6(12):e29191. doi:10.1371/journal.pone.0029191

6. Rahman M, Ismat F, McPherson MJ, Baldwin SA (2007) Topology-informed strategies for the overexpression and purification of membrane proteins. Mol Membr Biol 24(5-6):407-418. doi:10.1080/09687860701243998

7. Löw C, Jegerschöld C, Kovermann M, Moberg P, Nordlund P (2012) Optimisation of overexpression in E. coli and biophysical characterisation of human membrane protein synaptogyrin 1. PLoS One 7(6):e38244. doi:10.1371/journal.pone.0038244 
8. Bill RM, Henderson PJF, Iwata S, Kunji ERS, Michel H, Neutze R, Newstead S, Poolman B, Tate CG, Vogel H (2011) Overcoming barriers to membrane protein structure determination. Nat Biotechnol 29:335-340. doi:10.1038/nbt.1833

9. Schlegel S, Löfblom J, Lee C, Hjelm A, Klepsch M, Strous M, Drew D, Slotboom DJ, de Gier JW (2012) Optimizing membrane protein overexpression in the Escherichia coli strain Lemo21(DE3). J Mol Biol 423(4):648-659. doi:10.1016/j.jmb.2012.07.019

10. Egloff P, Hillenbrand M, Klenk C, Batyuk A, Heine P, Balada S, Schlinkmann KM, Scott DJ, Schütz M, Plückthun A (2014) Structure of signaling-competent neurotensin receptor 1 obtained by directed evolution in Escherichia coli. Proc NatiAcademy of Sciences 111(6):E655-662 11. Roosild TP, Greenwald J, Vega M, Castronovo S, Riek R, Choe S (2005) NMR structure of Mistic, a membrane-integrating protein for membrane protein expression. Science 307(5713):13171321

12. Hsu M-F, Yu T-F, Chou C-C, Fu H-Y, Yang C-S, Wang AHJ (2013) Using Haloarcula marismortui bacteriorhodopsin as a fusion tag for enhancing and visible expression of integral membrane proteins in Escherichia coli. PLoS One 8(2):e56363. doi:10.1371/journal.pone.0056363 13. Wagner S, Bader ML, Drew D, de Gier JW (2006) Rationalizing membrane protein overexpression. Trends Biotechnol 24(8):364-371. doi:10.1016/j.tibtech.2006.06.008 14. Manley DM, McComb ME, Perreault H, Donald LJ, Duckworth HW, O'Neil JD (2000) Secondary structure and oligomerization of the E. coli glycerol facilitator. Biochemistry 39(40):12303-12311. doi:10.1021/bi000703t

15. Trometer C, Falson P (2010) Mammalian membrane protein expression in baculovirus-infected insect cells. Methods Mol Biol 601:105-117. doi:10.1007/978-1-60761-344-2_7 16. Harrison RL, Jarvis DL (2006) Protein N - glycosylation in the baculovirus - insect cell expression system and engineering of insect cells to produce "mammalianized" recombinant glycoproteins. In: Adv Virus Res, vol 68. Academic Press, pp 159-191. doi: 10.10116/S0065$3527(06) 68005-6$ 
17. Palmberger D, Wilson IBH, Berger I, Grabherr R, Rendic D (2012) SweetBac: A new approach for the production of pammalianised glycoproteins in insect cells. PLoS One 7(4):e34226. doi:10.1371/journal.pone.0034226

18. Thomas JA, Tate CG (2014) Quality control in eukaryotic membrane protein overproduction. J Mol Biol 426(24):4139-4154. doi: 10.1016/j.jmb.2014.10.012

19. Deacon SE, Roach PCJ, Postis VLG, Wright GSA, Xia X, Phillips SEV, Paul Knox J, Henderson PJF, McPherson MJ, Baldwin SA (2008) Reliable scale-up of membrane protein over-expression by bacterial auto-induction: from microwell plates to pilot scale fermentations. Mol Membr Biol 25(8):588-598. doi:10.1080/09687680802511774

20. Terpe K (2006) Overview of bacterial expression systems for heterologous protein production: from molecular and biochemical fundamentals to commercial systems. Appl Microbiol Biotechnol 72(2):211-222. doi:10.1007/s00253-006-0465-8

21. Ma C, Hao Z, Huysmans G, Lesiuk A, Bullough P, Wang Y, Bartlam M, Phillips SE, Young JD, Goldman A, Baldwin SA, Postis VLG (2015) A versatile strategy for production of membrane proteins with diverse topologies: application to investigation of bacterial homologues of human divalent metal ion and nucleoside Transporters. PLoS One 10(11):e0143010.

doi:10.1371/journal.pone.0143010

22. Munro S, Pelham HR (1984) Use of peptide tagging to detect proteins expressed from cloned genes: deletion mapping functional domains of Drosophila hsp 70. EMBO J 3(13):3087-3093

23. Veesler D, Blangy S, Cambillau C, Sciara G (2008) There is a baby in the bath water: AcrB contamination is a major problem in membrane-protein crystallization. Acta Crystallogr Sect F Struct Biol Cryst Commun 64(Pt 10):880-885. doi:10.1107/S1744309108028248

24. Vergis JM, Wiener MC (2011) The variable detergent sensitivity of proteases that are utilized for recombinant protein affinity tag removal. Protein Expr Purif 78(2):139-142.

doi:10.1016/j.pep.2011.04.011

25. Miroux B, Walker JE (1996) Over-production of proteins in Escherichia coli: mutant hosts that allow synthesis of some membrane proteins and globular proteins at high levels. J Mol Biol 260(3):289-298. doi:10.1006/jmbi.1996.0399 
26. Dumon-Seignovert L, Cariot G, Vuillard L (2004) The toxicity of recombinant proteins in Escherichia coli: a comparison of overexpression in BL21(DE3), C41(DE3), and C43(DE3). Protein Expr Purif 37(1):203-206. doi:10.1016/j.pep.2004.04.025

27. Wagner S, Klepsch MM, Schlegel S, Appel A, Draheim R, et al. (2008) Tuning Escherichia coli for membrane protein overexpression. Proc NatlAcad Sci U S A 105(38):14371-14376. doi:10.1073/pnas.0804090105

28. Moffatt BA, Studier FW (1987) T7 lysozyme inhibits transcription by T7 RNA polymerase. Cell 49(2):221-227. doi:10.1016/0092-8674(87)90563-0

29. Studier FW (2005) Protein production by auto-induction in high-density shaking cultures. Prot Expr Purif 41(1):207-234

30. Schindelin J, Arganda-Carreras I, Frise E, Kaynig V, Longair M, et al. (2012) Fiji: an open-source platform for biological-image analysis. Nat Methods 9(7):676-682. doi:10.1038/nmeth.2019 31. Wilde M, Klausberger M, Palmberger D, Ernst W, Grabherr R (2014) Tnao38, high five and Sf9-evaluation of host-virus interactions in three different insect cell lines: baculovirus production and recombinant protein expression. Biotechnol Lett 36(4):743-749. doi:10.1007/s10529-013-1429-6 32. Hattori T, Nakanishi K, Mori T, Tomita M, Tsumoto K (2016) The method used to culture host cells (Sf9 cells) can affect the qualities of baculovirus budding particles expressing recombinant proteins. Biosci Biotechnol Biochem 80(3):445-451. doi:10.1080/09168451.2015.1101331 33. Smith GE, Vlak JM, Summers MD (1982) In Vitro Translation of Autographa californica Nuclear Polyhedrosis Virus Early and Late mRNAs. J Virol 44(1):199-208

34. Ciccarone VC, Polayes DA, Luckow VA (1998) Generation of recombinant baculovirus DNA in E. coli using a baculovirus shuttle vector. Methods Mol Med 13:213-235. doi:10.1385/0-89603-485$2: 213$

35. Ratnala VRP, Swarts HGP, VanOostrum J, Leurs R, DeGroot HJM, Bakker RA, DeGrip WJ (2004) Large-scale overproduction, functional purification and ligand affinities of the His-tagged human histamine H1 receptor. Eur Journal Biochem 271(13):2636-2646. doi:10.1111/j.14321033.2004.04192.x 
36. Cherezov V, Rosenbaum DM, Hanson MA, Rasmussen SGF, Thian FS, Kobilka TS, Choi HJ, Kuhn P, Weis WI, Kobilka BK, Stevens RC (2007) High-resolution crystal structure of an engineered human beta2-adrenergic G protein-coupled receptor. Science 318(5854):1258-1265.

doi:10.1126/science. 1150577

37. Jorio H, Tran R, Kamen A (2006) Stability of serum-free and purified baculovirus stocks under various storage conditions. Biotechnol Prog 22(1):319-325. doi:10.1021/bp050218v

38. Wasilko DJ, Edward Lee S, Stutzman-Engwall KJ, Reitz BA, Emmons TL, Mathis KJ, Bienkowski MJ, Tomasselli AG, David Fischer H (2009) The titerless infected-cells preservation and scale-up (TIPS) method for large-scale production of NO-sensitive human soluble guanylate cyclase (sGC) from insect cells infected with recombinant baculovirus. Protein Expr Purif 65(2):122-132. doi:10.1016/J.PEP.2009.01.002

39. Rosen BP (1986) Ion extrusion systems in Escherichia coli. In: Methods Enzymol, vol 125. Academic Press, pp 328-336

40. Belogurov GA, Lahti R (2002) A lysine substitute for $\mathrm{K}+$. A460K mutation eliminates $\mathrm{K}+$ dependence in $\mathrm{H}+$-pyrophosphatase of Carboxydothermus hydrogenoformans. J Biol Chem 277(51):49651-49654. doi:10.1074/jbc.M210341200

41. Bradford MM (1976) A rapid and sensitive method for the quantitation of microgram quantities of protein utilizing the principle of protein-dye binding. Anal Biochem 72(1):248-254.

doi:10.1006/abio.1976.9999

42. Stetsenko A, Guskov A (2017) An overview of the top ten detergents used for membrane protein crystallization. Crystals 7(7):197. doi:10.3390/cryst7070197

43. Zhao Y, Chapman DAG, Jones IM (2003) Improving baculovirus recombination. Nucleic Acids Res 31(2):E6-6. doi:10.1093/nar/gng006

44. Kitts PA, Ayres MD, Possee RD (1990) Linearization of baculovirus DNA enhances the recovery of recombinant virus expression vectors. Nucleic Acids Res 18(19):5667-5672. doi:10.1093/nar/18.19.5667

45. Hitchman RB, Possee RD, Siaterli E, Richards KS, Clayton AJ, Bird LE, Owens RJ, Carpentier DCJ, King FL, Danquah JO, Spink KG, King LA (2010) Improved expression of secreted and 
membrane-targeted proteins in insect cells. Biotechnol Appl Biochem 56(3):85-93.

doi:10.1042/BA20090130

46. Hitchman RB, Possee RD, Crombie AT, Chambers A, Ho K, Siaterli E, Lissina O, Sternard H, Novy R, Loomis K, Bird LE, Owens RJ, King LA (2010) Genetic modification of a baculovirus vector for increased expression in insect cells. Cell Biol Toxicol 26(1):57-68. doi:10.1007/s10565009-9133-y

47. Possee RD, Hitchman RB, Richards KS, Mann SG, Siaterli E, Nixon CP, Irving H, Assenberg R, Alderton D, Owens RJ, King LA (2008) Generation of baculovirus vectors for the high-throughput production of proteins in insect cells. Biotechnol Bioeng 101(6):1115-1122. doi:10.1002/bit.22002 48. Luckow VA, Lee SC, Barry GF, Olins PO (1993) Efficient generation of infectious recombinant baculoviruses by site-specific transposon-mediated insertion of foreign genes into a baculovirus genome propagated in Escherichia coli. Jo Virol 67(8):4566-4579

49. Pijlman GP, van Schijndel JE, Vlak JM (2003) Spontaneous excision of BAC vector sequences from bacmid-derived baculovirus expression vectors upon passage in insect cells. J GenVirol 84(10):2669-2678. doi:10.1099/vir.0.19438-0

50. Hu YK, Kaplan JH (2000) Site-directed chemical labeling of extracellular loops in a membrane protein. The topology of the Na,K-ATPase alpha-subunit. J Biol Chem 275(25):19185-19191. doi:10.1074/jbc.M000641200

51. Yang B, van Hoek AN, Verkman AS (1997) Very high single channel water permeability of aquaporin-4 in baculovirus-infected insect cells and liposomes reconstituted with purified aquaporin4. Biochemistry 36(24):7625-7632. doi:10.1021/bi970231r

52. Chaga G, Hopp J, Nelson P (1999) Immobilized metal ion affinity chromatography on Co2+carboxymethylaspartate-agarose Superflow, as demonstrated by one-step purification of lactate dehydrogenase from chicken breast muscle. Biotechnol Appl Biochem 29(1):19-24

53. Kawate T, Gouaux E (2006) Fluorescence-detection size-exclusion chromatography for precrystallization screening of integral membrane proteins. Structure 14(4):673-681. doi:10.1016/j.str.2006.01.013 
54. Binns KL, Taylor PP, Sicheri F, Pawson T, Holland SJ (2000) Phosphorylation of tyrosine residues in the kinase domain and juxtamembrane region regulates the biological and catalytic activities of Eph receptors. Mol Cell Biol 20(13):4791-4805. doi:10.1128/mcb.20.13.4791-4805.2000 55. Wiepz GJ, Guadaramma AG, Fulgham DL, Bertics PJ (2006) Purification and assay of kinaseactive EGF receptor from mammalian cells by immunoaffinity chromatography. In: Patel TB, Bertics PJ (eds) Epidermal Growth Factor: Methods in Molecular Biology, vol 327. Humana Press, Totowa, New Jersey, pp 25-38. doi:10.1385/1-59745-012-X:25

56. Xie H, Patching SG, Gallagher MP, Litherland GJ, Brough AR, et al. (2004) Purification and properties of the Escherichia coli nucleoside transporter NupG, a paradigm for a major facilitator transporter sub-family. Mol Membr Biol. 21(5):323-336. doi:10.1080/09687860400003941

57. Kimple ME, Brill AL, Pasker RL (2013) Overview of affinity tags for protein purification. Curr Protoc Protein Sci. 73(1):Unit-9.9. doi:10.1002/0471140864.ps0909s73

58. Kozma D, Simon I, Tusnády GE (2012) PDBTM: Protein Data Bank of transmembrane proteins after 8 years. Nucleic Acids Res 41(D1):D524-D529. doi:10.1093/nar/gks1169

59. Stark MJR (1987) Multicopy expression vectors carrying the lac represser gene for regulated high-level expression of genes in Escherichia coli. Gene 51(2):255-267. doi:10.1016/0378$1119(87) 90314-3$

60. Skerra A (1994) Use of the tetracycline promoter for the tightly regulated production of a murine antibody fragment in Escherichia coli. Gene 151(1):131-135. doi:10.1016/0378-1119(94)90643-2 61. Guzman LM, Belin D, Carson MJ, Beckwith JON (1995) Tight regulation, modulation, and highlevel expression by vectors containing the arabinose PBAD promoter. J Bacteriol 177(14):4121-4130. doi:10.1128/jb.177.14.4121-4130.1995

62. Park SH, Casagrande F, Chu M, Maier K, Kiefer H, Opella SJ (2012) Optimization of purification and refolding of the human chemokine receptor CXCR1 improves the stability of proteoliposomes for structure determination. Biochim Biophys Acta 1818(3):584-591. doi:10.1016/j.bbamem.2011.10.008 63. Tait AR, Straus SK (2011) Overexpression and purification of U24 from human herpesvirus type6 in E. coli: unconventional use of oxidizing environments with a maltose binding protein-hexahistine 
dual tag to enhance membrane protein yield. Microb Cell Fact 10(1):51. doi:10.1186/1475-2859-1051

64. Stanasila L, Massotte D, Kieffer BL, Pattus F (1999) Expression of $\delta$, $\kappa$ and $\mu$ human opioid receptors in Escherichia coli and reconstitution of the high-affinity state for agonist with heterotrimeric G proteins. Eur J Biochem 260(2):430-438. doi:10.1046/j.1432-1327.1999.00187.x 65. Weiß HM, Grisshammer R (2002) Purification and characterization of the human adenosine A2a receptor functionally expressed in Escherichia coli. Eur J Biochem 269(1):82-92. doi:10.1046/j.00142956.2002.02618.x

66. Chaudhary S, Pak JE, Pedersen BP, Bang LJ, Zhang LB, Ngaw SMM, Green RG, Sharma V, Stroud RM (2011) Efficient expression screening of human membrane proteins in transiently transfected Human Embryonic Kidney 293S cells. Methods 55(4):273-280.

doi:10.1016/j.ymeth.2011.08.018

67. Bird LE, Rada H, Verma A, Gasper R, Birch J, Jennions M, Löwe J, Moraes I, Owens RJ (2015) Green fluorescent protein-based expression screening of membrane proteins in Escherichia coli. J Vis Exp (95):e5235. doi:10.3791/52357

68. Goehring A, Lee CH, Wang KH, Michel JC, Claxton DP, et al. (2014) Screening and large-scale expression of membrane proteins in mammalian cells for structural studies. Nat Protoc 9(11):2574. doi:10.1038/nprot.2014.173

69. Douette P, Navet R, Gerkens P, Galleni M, Lévy D, Sluse FE (2005) Escherichia coli fusion carrier proteins act as solubilizing agents for recombinant uncoupling protein 1 through interactions with GroEL. Biochem Biophys Res Commun 333(3):686-693. doi:10.1016/j.bbrc.2005.05.164 70. Yeliseev A, Zoubak L, Gawrisch K (2007) Use of dual affinity tags for expression and purification of functional peripheral cannabinoid receptor. Protein Expr Purif 53(1):153-163. doi:10.1016/j.pep.2006.12.003

71. Therien AG, Glibowicka M, Deber CM (2002) Expression and purification of two hydrophobic double-spanning membrane proteins derived from the cystic fibrosis transmembrane conductance regulator. Protein Expr Purif 25(1):81-86. doi:10.1006/prep.2001.1612 
72. Kefala G, Kwiatkowski W, Esquivies L, Maslennikov I, Choe S (2007) Application of Mistic to improving the expression and membrane integration of histidine kinase receptors from Escherichia coli. J Struct Funct Genomics 8(4):167-172. doi:10.1007/s10969-007-9033-4

73. Marino J, Bordag N, Keller S, Zerbe O (2015) Mistic's membrane association and its assistance in overexpression of a human GPCR are independent processes. Protein Sci 24(1):38-48.

doi:10.1002/pro. 2582

74. Alves NS, Astrinidis SA, Eisenhardt N, Sieverding C, Redolfi J, et al. (2017) MISTIC-fusion proteins as antigens for high quality membrane protein antibodies. Sci Rep 7(1):41519.

doi:10.1038/srep41519

75. Zuo X, Mattern MR, Tan R, Li S, Hall J, et al. (2005) Expression and purification of SARS coronavirus proteins using SUMO-fusions. Protein Expr Purif 42(1):100-110.

doi:10.1016/j.pep.2005.02.004

76. Zuo X, Li S, Hall J, Mattern MR, Tran H, Shoo J, Tan R, Weiss SR, Butt TR (2005) Enhanced expression and purification of membrane proteins by SUMO fusion in Escherichia coli. J Struct Funct Genomics 6(2):103-111. doi:10.1007/s10969-005-2664-4

77. Rayavara K, Rajapandi T, Wollenberg K, Kabat J, Fischer ER, Desai SA (2009) A complex of three related membrane proteins is conserved on malarial merozoites. Mol Biochem Parasitol 167(2):135-143. doi:10.1016/j.molbiopara.2009.05.006

78. Wang Z, Li H, Guan W, Ling H, Wang Z, Mu T, Shuler FD, Fang X (2010) Human SUMO fusion systems enhance protein expression and solubility. Protein Expr Purif 73(2):203-208.

doi:10.1016/j.pep.2010.05.001

79. Wang Z, Li N, Wang Y, Wu Y, Mu T, Zheng Y, Huang L, Fang X (2012) Ubiquitin-intein and SUMO2-intein fusion systems for enhanced protein production and purification. Protein Expr Purif 82(1):174-178. doi:10.1016/j.pep.2011.11.017

80. Engel CK, Chen L, Privé GG (2002) Insertion of carrier proteins into hydrophilic loops of the Escherichia coli lactose permease. Biochim Biophys Acta 1564(1):38-46. doi:10.1016/S00052736(02)00398-X 
81. Granier S, Manglik A, Kruse AC, Kobilka TS, Thian FS, Weis WI, Kobilka BK (2012) Structure of the $\delta$-opioid receptor bound to naltrindole. Nature 485(7398):400-404. doi:10.1038/nature11111 82. Kruse AC, Hu J, Pan AC, Arlow DH, Rosenbaum DM, et al. (2012) Structure and dynamics of the M3 muscarinic acetylcholine receptor. Nature 482(7386):552-556. doi:10.1038/nature10867 83. Chun E, Thompson AA, Liu W, Roth CB, Griffith MT, et al. (2012) Fusion partner toolchest for the stabilization and crystallization of G protein-coupled receptors. Structure 20(6):967-976. doi:10.1016/j.str.2012.04.010

84. Jaakola VP, Griffith MT, Hanson MA, Cherezov V, Chien EYT, et al. (2008) The 2.6 angstrom crystal structure of a human A2A adenosine receptor bound to an antagonist. Science 322(5905):1211-1217. doi:10.1126/science.1164772

85. Mathew E, Ding F-X, Naider F, Dumont ME (2013) Functional fusions of T4 lysozyme in the third intracellular loop of a $\mathrm{G}$ protein-coupled receptor identified by a random screening approach in yeast. Protein Eng Des Sel 26(1):59-71. doi:10.1093/protein/gzs070

86. Pestov NB, Rydström J (2007) Purification of recombinant membrane proteins tagged with calmodulin-binding domains by affinity chromatography on calmodulin-agarose: example of nicotinamide nucleotide transhydrogenase. Nat Protoc 2(1):198-202. doi:10.1038/nprot.2006.456 87. Maurice S, Dekel M, Shoseyov O, Gertler A (2003) Cellulose beads bound to cellulose binding domain-fused recombinant proteins; an adjuvant system for parenteral vaccination of fish. Vaccine 2(23):3200-3207. doi:10.1016/S0264-410X(03)00231-7

88. Neophytou I, Harvey R, Lawrence J, Marsh P, Panaretou B, Barlow D (2007) Eukaryotic integral membrane protein expression utilizing the Escherichia coli glycerol-conducting channel protein (GlpF). Appl Microbiol Biotechnol 77(2):375-381. doi:10.1007/s00253-007-1174-7

89. Kumar A, Ward P, Katre UV, Mohanty S (2012) A novel and simple method of production and biophysical characterization of a mini-membrane protein, Ost4p: a subunit of yeast oligosaccharyl transferase. Biopolymers 97(7):499-507. doi:10.1002/bip.22028 90. Su PC, Si W, Baker DL, Berger BW (2013) High-yield membrane protein expression from E. coli using an engineered outer membrane protein F fusion. Protein Sci 22(4):434-443.

doi:10.1002/pro.2224 
91. Jappelli R, Perrin MH, Lewis KA, Vaughan JM, Tzitzilonis C, et al. (2014) Expression and functional characterization of membrane-integrated mammalian corticotropin releasing factor receptors 1 and 2 in Escherichia coli. PloS One 9(1):e84013-e84013.

doi:10.1371/journal.pone.0084013

92. Suzuki KGN, Kasai RS, Fujiwara TK, Kusumi A (2013) Chapter 20 - Single-molecule imaging of receptor-receptor interactions. In: Conn PM (ed) Methods in Cell Biology, vol 117. Academic Press, pp 373-390. doi:10.1016/B978-0-12-408143-7.00020-7

93. Locatelli-Hoops S, Sheen FC, Zoubak L, Gawrisch K, Yeliseev AA (2013) Application of HaloTag technology to expression and purification of cannabinoid receptor CB2. Protein Expr Purif 89(1):62-72. doi:10.1016/j.pep.2013.02.011

94. Wang H, Li X, Nakane S, Liu S, Ishikawa H, Iwamoto A, Matsuda Z (2014) Co-expression of foreign proteins tethered to HIV-1 envelope glycoprotein on the cell surface by introducing an intervening second membrane-spanning domain. PloS One 9(5):e96790-e96790. doi:10.1371/journal.pone.0096790

95. Leviatan S, Sawada K, Moriyama Y, Nelson N (2010) Combinatorial method for overexpression of membrane proteins in Escherichia coli. J Biol Chem 285(31):23548-23556.

doi:10.1074/jbc.M110.125492

96. Londesborough J, Richard P, Valkonen M, Viljanen K (2014) Effect of C-terminal protein tags on pentitol and L-arabinose transport by Ambrosiozyma monospora Lat1 and Lat2 transporters in Saccharomyces cerevisiae. Appl Environ Microbiol 80(9):2737-2745. doi:10.1128/AEM.04067-13 97. Yim SK, Kim DH, Jung HC, Pan JG, Kang HS, Ahn T, Yun CH (2010) Surface display of hemeand diflavin-containing cytochrome P450 BM3 in Escherichia coli: a whole cell biocatalyst for oxidation. J Microbiol Biotechnol 20(4):712-717. doi:10.4014/jmb.0910.10043 98. Mizrachi D, Chen Y, Liu J, Peng HM, Ke A, et al. (2015) Making water-soluble integral membrane proteins in vivo using an amphipathic protein fusion strategy. Nat Commun 6:6826-6826. doi:10.1038/ncomms7826 
99. Pandey A, Shin K, Patterson RE, Liu XQ, Rainey JK (2016) Current strategies for protein production and purification enabling membrane protein structural biology. Biochem Cell Biol 94(6):507-527. doi:10.1139/bcb-2015-0143

\begin{tabular}{|c|c|c|}
\hline $\begin{array}{c}\text { Expression } \\
\text { system }\end{array}$ & Commonly used cell lines & $\begin{array}{c}\text { Percentage of total } \\
\text { membrane protein } \\
\text { structures }\end{array}$ \\
\hline Bacteria & $\begin{array}{c}\text { Escherichia coli }(\mathrm{BL} 21(\mathrm{DE} 3), \\
\text { C43(DE3)) }\end{array}$ & $69.1 \%$ \\
\hline Archaea & Halobacterium salinarum & $1.9 \%$ \\
\hline Yeast & $\begin{array}{c}\text { Pichia pastoris } \\
\text { Saccharomyces cerevisiae }\end{array}$ & $8.3 \%$ \\
\hline Insect cells & $\begin{array}{c}\text { Drosophila melanogaster }(\mathrm{S} 2) \\
\text { Spodoptera frugiperda }(S f 9, S f 21) \\
\text { Trichoplusia ni }(\text { High Five) }\end{array}$ & $8.1 \%$ \\
\hline $\begin{array}{c}\text { Mammalian } \\
\text { cells }\end{array}$ & $\begin{array}{c}\text { COS-1 } \\
\text { HEK293 } \\
\text { CHO }\end{array}$ & $12.1 \%$ \\
\hline $\begin{array}{c}\text { Cell-free protein } \\
\text { production }\end{array}$ & $\begin{array}{c}\text { E. coli-, wheat germ-, yeast-, insect } \\
\text { cell- and mammalian cell based }\end{array}$ \\
\hline Others & $/$ & $0.4 \%$ \\
\hline
\end{tabular}

Table 1: Membrane protein expression systems used to solve membrane protein structures. Numbers are extracted from PDB headers of all structure entries in PDBTM (58) (http://pdbtm.enzim.hu/, updated September 2019). Listed are calculated based on the 3390 (out of 4077) structures in PDBTM with annotated expression hosts.

\begin{tabular}{|l|l|l|l|}
\hline Vectors & Promoter & Inducer & Reference \\
\hline pTTQ18 & Ptac & IPTG & Stark et al. (59) \\
\hline pET vectors & T7lac & IPTG & Novagen \\
\hline pASK-IBA & Tet & $\begin{array}{l}\text { Anhydrotetracycline } \\
\text { Atc }\end{array}$ & $\begin{array}{l}\text { IBA Lifescience; } \\
\text { Skerra (60) }\end{array}$ \\
\hline pBAD & PAD $_{\text {BAD }}$ & Arabinose & Guzman et al. (61) \\
\hline
\end{tabular}

Table 2: Summary of the most common plasmids and promoters used for bacterial expression. 


\begin{tabular}{|c|c|c|}
\hline Protein fusion tag & $\begin{array}{l}\text { Expression } \\
\text { svstem }\end{array}$ & Example references \\
\hline $\begin{array}{l}\text { Glutathione S transferase } \\
\text { (GST) }\end{array}$ & E. coli & Park et al. (62) \\
\hline $\begin{array}{l}\text { Maltose binding protein } \\
\text { (MBP) }\end{array}$ & E. coli & $\begin{array}{l}\text { Tait et al. (63), Stanasila et al. (64), Weiss } \\
\text { et al. (65) }\end{array}$ \\
\hline $\begin{array}{l}\text { Green fluorescence protein } \\
\text { (GFP) }\end{array}$ & $\begin{array}{l}\text { Mammalian, } \\
\text { insect, yeast, } E \text {. } \\
\text { coli }\end{array}$ & $\begin{array}{l}\text { Kawate and Gouaux (53), Chaudhary et al. } \\
\text { (66), Bird et al. (67), Goehring (68) }\end{array}$ \\
\hline $\begin{array}{l}\text { N-utilization substance (Nus } \\
\text { A) }\end{array}$ & E. coli & Douette et al. (69) \\
\hline Thioredoxin (Trx) & E. coli & Yeliseev et al. (70), Therien et al. (71) \\
\hline $\begin{array}{l}\text { Haloarcula marismortui } \\
\text { Bacteriorhodopsin } \\
\text { (HmBRI/D94N) }\end{array}$ & E. coli & Hsu et al. (12) \\
\hline Mistic & E. coli & $\begin{array}{l}\text { Roosild et al. (11), Kefala et al. (72), } \\
\text { Marino et al. (73), Alves et al. (74) }\end{array}$ \\
\hline $\begin{array}{l}\text { Small ubiquitin-related } \\
\text { modifier (SUMO) }\end{array}$ & Insect, E. coli & $\begin{array}{l}\text { Zuo et al. (75), Zuo et al. (76), Rayavara et } \\
\text { al. (77), Wang et al. (78) }\end{array}$ \\
\hline Ubiquitin & E. coli & Wang et al. (78) Wang et al. (79) \\
\hline Intein & E. coli & Wang et al. (79) \\
\hline T4 lysozyme & $\begin{array}{l}\text { Insect, yeast, } E \text {. } \\
\text { coli }\end{array}$ & $\begin{array}{l}\text { Engel et al. (80), Granier et al. (81), Kruse } \\
\text { et al. (82), Chun et al. (83), Jaakola et al. } \\
\text { (84), Cherezov et al. (36), Mathew et al. } \\
\text { (85) }\end{array}$ \\
\hline $\begin{array}{l}\text { Calmodulin binding peptide } \\
\text { (CBP) }\end{array}$ & E. coli & Pestov and Rydström (86) \\
\hline $\begin{array}{l}\text { Cellulose binding domain } \\
\text { (CBD) }\end{array}$ & E. coli & Maurice et al. (87) \\
\hline $\begin{array}{l}\text { Glycerol-conducting channel } \\
\text { protein }(\mathrm{GlpF})\end{array}$ & E. coli & Manley et al. (14), Neophytou et al. (88) \\
\hline $\begin{array}{l}\text { IgG domain of } \mathrm{B} 1 \text { of protein } \\
\mathrm{G}(\mathrm{GB} 1)\end{array}$ & E. coli & Kumar et al. (89) \\
\hline $\begin{array}{l}\text { Outer membrane protein } \mathrm{F} \\
\text { fusion }(\mathrm{pOmpF})\end{array}$ & E. coli & Su et al. (90) \\
\hline $\begin{array}{l}\text { Disulfide oxidoreductase A } \\
\text { (DSBA) }\end{array}$ & E. coli & Jappelli et al. (91) \\
\hline Halo tag & $\begin{array}{l}\text { Mammalian, } E \text {. } \\
\text { coli }\end{array}$ & $\begin{array}{l}\text { Suzuki et al. (92), Locatelli et al. (93), } \\
\text { Wang et al.(94) }\end{array}$ \\
\hline $\begin{array}{l}\text { Regulator of frmRAB operon } \\
\text { (YaiN) }\end{array}$ & E. coli & Leviatan et al. (95) \\
\hline YbeL & E. coli & Leviatan et al. (95) \\
\hline $\begin{array}{l}\text { Thermostabilized } \\
\left.\text { apocytochrome b562 ( } b_{562} \mathrm{RIL}\right)\end{array}$ & Insect & Chun et al. (83) \\
\hline Adenylate kinase $(\mathrm{AK})$ & Yeast & Londesborough et al. (96) \\
\hline Ice nucleation protein (Inp) & E. coli & Yim et al. (97) \\
\hline Apolipoprotein A-I (ApoAI) & E. coli & Mizrachi et al. (98) \\
\hline
\end{tabular}

Table 3: Summary of protein tags used for membrane protein purification. Modified from Pandey et al. (99) 


\begin{tabular}{|c|c|c|c|}
\hline Name (Abbreviation) & Type & CMC & Structure \\
\hline Fos-choline 12 (FC-12) & zwitterionic & $0.047 \%$ & \\
\hline n-Dodecyl $\beta$-D-maltoside (DDM) & non-ionic & $0.0087 \%$ & \\
\hline n-Decyl- $\beta$-D-maltoside (DM) & non-ionic & $0.087 \%$ & \\
\hline n-Octyl- $\beta$-D-glucoside (OG) & non-ionic & $0.53 \%$ & \\
\hline $\begin{array}{l}\text { Lauryl maltose neopentyl glycol } \\
\text { (LMNG) }\end{array}$ & non-ionic & $0.001 \%$ & \\
\hline $\begin{array}{l}\text { 5-Cyclohexyl-1-pentyl- } \beta \text {-D- } \\
\text { maltoside (CYMAL-5) }\end{array}$ & non-ionic & $0.12 \%$ & \\
\hline Dodecyl octaglycol (C12E8) & non-ionic & $0.0048 \%$ & \\
\hline $\begin{array}{l}\text { Lauryldimethylamine oxide } \\
\text { (LDAO) }\end{array}$ & zwitterionic & $0.023 \%$ & \\
\hline Digitonin & non-ionic & $0.03 \%$ & \\
\hline $\begin{array}{l}\text { 3-[(3-Cholamidopropyl) } \\
\text { dimethylammonio]-1- } \\
\text { propanesulfonate (CHAPS) }\end{array}$ & zwitterionic & $0.49 \%$ & \\
\hline
\end{tabular}

Table 4: Commonly used detergents for membrane protein solubilization for structural studies. CMC: critical micelle concentration. 


\section{Figure Captions:}

Fig. 1. Counting cells with a haematocytometer. A big square is distinguished by triple-lined borders (yellow), which usually contains $4 \times 4$ smaller squares. Countable cells are represented as green circles whereas cells that need to be excluded are shown as red circles. Cells fall within the right and bottom borders are excluded in this example. Depending on preference, cells fall within the left and top borders can be excluded otherwise.

Fig. 2 Baculovirus-transfected $S f 9$ cells showing expressed receptor tyrosine kinase carrying a Cterminal GFP tag localizes to the plasma membrane under a laser confocal microscope $(40 \times$ magnification). Transfected $S f 9$ cells were exposed under white light (A) or excited at $488 \mathrm{~nm}$ (B) for green fluorescence detection. (C) Merged images from fluorescence and white light imaging (A and B).

Fig. 3. Examples of detergent solubilization screening of $S f 9$ expressed His-tagged RET receptor tyrosine kinase fused with a C-terminal GFP $(180 \mathrm{kDa})$, prepared using the sucrose cushion method (described in section 4.3.4). In-gel fluorescence (A) and anti-His Western blot (B) show the solubilization efficiency of RET from the lower sucrose fraction in 2\% FC-12, LMNG, OG or CYMAL-5 supplemented with $0.2 \%$ CHS. The ratio of band intensities of Solubilised fraction (SN) to Total fraction (TP) was analysed using ImageJ and solubility percentage was calculated (C). TP: total protein; SN: supernatant; Std: protein standard marker.

Fig. 4. SDS-PAGE images showing anti-Flag resin purified RET receptor tyrosine kinase fused with a C-terminal GFP (180 kDa). Gels were first imaged for in-gel fluorescence detection (F) and subsequently stained with Coomassie Blue (C) to show the band migration on the gel of purified fulllength RET. E: eluate; Std: protein standard marker. 